\title{
Vergangenheitsbewältigung: The Legacy of the Past
}

It was not until the 1960s that Hochwälder directly confronted the Nazi period in his dramas; a traumatic time that not only took a horrendous personal toll but led him to change occupation and become a professional dramatist. Nevertheless, the moral dilemmas and issues portrayed in earlier dramas clearly have more than a passing relevance to the European history Hochwälder witnessed $^{1}$, and such themes appear again in those dramas directly concerned with the National Socialist legacy. The move to a more contemporary setting and direct confrontation with modern problems is first notable in the plays 1003 and Donnerstag, and it is during this period that the first overt attempt to address the Nazi past, Holokaust (1961), was written, followed chronologically by Der Himbeerpflücker (1964) and Der Befehl (1967 and 1968). In doing this, however, Hochwälder chose not to follow the same path to documentary theatre employed by fellow playwrights such as Hochhuth, Weiss ${ }^{2}$ and Kipphardt, and, while his plays have a discernable factual basis, their characters and plots remain strictly fictional. This has the advantage of largely avoiding distracting questions concerning historical accuracy ${ }^{3}$ and debates about the portrayal of historical figures, and is therefore better able to focus on the behaviour of ordinary individuals confronted by terrible circumstances. He is concerned not with portraying the almost incomprehensible horrors of the concentration camp or attacking religious and political leaders, but with observing how ordinary individuals can be drawn into a destructive web of evil.

Yet surprisingly, considering Hochwälder's willingness to confront the Nazi past squarely in the 1960 s, he returns to a historical setting in the last of his dramas to explore the theme of Vergangenheitsbewältigung, Die Prinzessin von Chimay. Perhaps partly from a fear of the play becoming too zeitverbunden, or simply from his persistent interest in the French Revolution ${ }^{4}$,

${ }^{1}$ Hochwälder acknowledged that the historical settings of many of his earlier dramas merely served as a guise for his thematic concerns, a device he moved away from after the play, Die Herberge. Cf. Im Wechsel der Zeit, 94.

2 In correspondence Hochwälder was particularly scathing of Die Ermittlung: “[...] der Auschwitzprozess als versifiziertes Oratorium, d.h. der getreue Protokoll-Text, bloss ohne Punkte und Beistriche, verschmockt und geschmacklos bis zum Exzess - garantiert ein Erfolg, aber dennoch lob ich mir dagegen meine Deppen-Posse [Der Himbeerpflïcker]" [Brief an Ernst Waldinger, 5. Juli 1965, Dokumentationsstelle für neuere österreichische Literatur, Wien]. He also criticised the play's lack of dramatic qualities cf. Brief an Ernst Waldinger, 20. Dez. 1965, Dokumentationsstelle für neuere österreichische Literatur, Wien.

3 Although Hochwälder did feel the need to defend the accuracy of his portrayal of modern Austria in the satire, Der Himbeerpflücker. Cf. Im Wechsel der Zeit, 100.

4 An uncompleted typescript about the military leaders involved in the Battle of Valmy, which is mentioned in his essay "Kann die Freiheit überleben?", remained unfinished at the time of his death and is further evidence of his abiding interest in the period (see Chapter 7). Cf. Fritz 
this play can be seen as a sequel to the earlier drama, Der öffentliche Ankläger. Nevertheless, set four decades after Robespierre's Terror, it has more than a passing relevance to the time it was written, four decades after the defeat of European Fascism.

Several factors undoubtedly influenced Hochwälder's decision to write the three dramas dealing directly with National Socialism. Prominent court cases, notably the Eichmann and Auschwitz trials, brought Nazi crimes to the forefront of international attention in the 1960s, while in Israel the KastnerGrünwald libel case and appeal between 1953 to 1958 [see below] focused attention not just on Nazi atrocities but also the involvement of Jewish leaders in the Holocaust. In addition to these cases, scandalous affairs in Hochwälder's native Austria, such as the official response to the anti-Semitic remarks made in lectures by Professor Borodajkewycz and the trials of war criminals such as Franz Novak, which showed a disturbing propensity for light sentences or acquittal, horrified Hochwälder ${ }^{5}$. Such concerns were highlighted by the Simon Wiesenthal report in 1966 , which suggested there were as many as 1,100 free men living in Austria who were implicated in war crimes ${ }^{6}$. Alarm at this state of affairs formed the basis of the satirical attack on former Nazis in Der Himbeerpflücker.

While Hochwälder's concerns about the failure of society to bring to task those guilty of crimes against humanity, expressed in the plays, Der Himbeerpflïcker and Der Befehl, led to controversy and public debate, his first Auseinandersetzung with the Nazi past, Holokaust, remained unpublished in his lifetime. Thematically, the play has much in common with earlier dramas, and ultimately rejects, as did plays such as Donadieu and Der öffentliche Ankläger before it, any moral compromises with corrupting forces. However, what sets it apart from the later plays examining the effects

Hochwälder, "Der Feldzug. Schauspiel in drei Akten", ts., 1970[?]-1986 Hochwälder Nachlaß, Wiener Stadt- und Landesbibliothek, Wien.

5

In the frequent letters exchanged between Ernst Waldinger and Hochwälder, the failure of Austria to take such war criminals to task is a recurrent subject. [Cf. Briefe an Ernst Waldinger von Fritz Hochwälder: 13. April 1965 [Borodajkewycz]; 21. Mai 1965 [Novak]; 5. Juli 1965 [Borodajkewycz]; 31. Dez. 1965; 28. Feb. 1966; 6. Mai 1966; 25. Okt. 1966; 13. Nov. 1966, Dokumentationsstelle für neuere österreichische Literatur, Wien, and Briefe an Fritz Hochwälder von Ernst Waldinger: 27. Juni 1965 [Borodajkewycz]; 31. Dez. 1965; 28. Feb. 1966; 6. Mai 1966; 21. Juni 1966; 14. Okt. 1966 [Novak]; 4. Nov. 1966, Hochwälder Nachlaß, Wiener Stadt- und Landesbibliothek, Wien.] Such was Hochwälder's concern with events in Austria that he advised his friend, who was considering returning to live in Europe from the United States, not to consider Austria: "Denn unser Oesterreich ist unsichtbar regiert von den miesesten Nazis, ich weiss nicht, ob Sie den Fall Borodajkewicz [sic] verfolgt haben [...] Hitler war ja nur die Subsummierung des homo austriacus, wie sie ihn an allen Ecken und Enden in diesem wunderbaren Land begegnen können. Nein, Oesterreich ist kein Lokal mehr für uns!" ( Brief an Waldinger, 13. April 1965)

6 Anonymous, "Austria Accused by Investigator of Laxity in Trying Nazi Killers", The New York Times, Nov. 3 1966. This article was referred to in correspondence between Hochwälder and Waldinger. Cf. Ernst Waldinger, Brief an Fritz Hochwälder, 4. Nov. 1966, Dokumentationsstelle für neuere österreichische Literatur, Wien and Fritz Hochwälder, Brief an Ernst Waldinger, 13. Nov. 1966, Hochwälder Nachlaß, Wiener Stadt- und Landesbibliothek, Wien. 
of National Socialism, is that it does not examine the role of the Nazis, but explores the interaction of Jews themselves with the forces of their annihilation. Such subject matter would have been highly controversial and would have run the risk of much misunderstanding, and this as much as any dissatisfaction with the dramatic qualities of the drama might have persuaded Hochwälder not to complete the work ${ }^{7}$. Certainly, this risk and the danger of the play being used for anti-Semitic purposes were pointed out to Hochwälder ${ }^{8}$.

The drama is inspired by the Kastner-Grunwald libel case which rocked Israeli society between 1953 and 1958. The legal action resulted from allegations, made by the elderly pamphleteer Malchiel Grünwald, that Dr. Rudolf Kastner ${ }^{9}$, a senior government official, collaborated with the Nazis in Hungary in order to save a few prominent Jews, friends and family members. Kastner promptly sued for libel, but in a court case that quickly became highly politicised, a somewhat confusing tale of secret negotiations emerged, involving Jewish leaders in Budapest, SS officials in charge of the extermination of the Jews (including Adolf Eichmann and Kurt Becher), Zionist leaders in the then British Protectorate of Palestine, and the Allies. The story of Kastner's negotiations with the Nazis to save Hungarian Jews and Eichmann's so-called "blood for trucks" offer provided not just Hochwälder but also Heinar Kipphardt with dramatic inspiration ${ }^{10}$, and raised serious questions not just about Kastner's behaviour in Hungary but also about the efforts of Zionist leaders in Palestine and the rest of the world on behalf of the Jews being transported to the gas chambers in Europe ${ }^{11}$. These questions

7 It is this explanation that Bortenschlager [Der Dramatiker Fritz Hochwalder, 42] offers for Hochwälder's refusal to allow Esther, with its portrayal of victimised Jews, to be performed. Such considerations, however, cannot disguise the weaknesses of "Holokaust", most notably Glaser's motivation for going through with the trial, when suicide would seem a more likely avenue for a man seeking to end it all, and the rather melodramatic end and martyrdom of Rouzha.

8 Briefe von Hans Schubert an Fritz Hochwälder, 14. Juni 1961 und 20. Aug. 1961, Hochwälder Nachlaß, Wiener Stadt- und Landesbibliothek, Wien.

${ }^{9}$ His name is variously given as Kastner or Kasztner, first names as Rudolf, Resnö or Rezno. Matters are complicated by the fact that he himself chose to adopt different names at different times, prompting one highly critical commentator to cynically claim:

As a journalist working among Hungarians in Kluj [his home town], his name was Dr. Rezo Kastner. When he came to Budapest to work among the Germans, he called himself Dr. Rudolf Kastner. Arrived in Israel and embraced by the government clique as one of their own, he became Dr. Israel Kastner.

- Ben Hecht, Perfidy, (New York: Julian Messner, 1961), 208.

10 Heinar Kipphardt, Joel Brand. Die Geschichte eines Geschäfts, 1965, Theaterstücke, Band 2, von Kipphardt, (Köln: Kiepenheuer \& Witsch, 1981), 7-105.

11 Cf. Randolph L. Braham, "Rescue and Resistance", The Politics of Genocide. The Holocaust in Hungary, by Braham, Vol. 2 (New York: Columbia University Press, 1981), 922 1026; Yehuda Bauer, "The Mission of Joel Brand", The Holocaust in Historical Perspective, by Bauer, (Seattle: University of Washington Press, 1978), 94-155; and Lenni Brenner, "Hungary, the Crime within a Crime", Zionism in the Age of the Dictators, by Brenner, (London: Croom Helm, 1983), 252-264. For a thorough historical examination of this whole issue, which amongst other things strongly defends Kastner against his detractors, see Yehuda Bauer, Jews for Sale? Nazi-Jewish Negotiations, 1933-1945 (New Haven: Yale University, 1994). 
again surfaced in 1960 when Eichmann was brought to Jerusalem for trial and the spotlight returned to the fate of the Hungarian Jews, although Kastner was not longer alive to testify in this case ${ }^{12}$. The debate about Jewish complicity in the Holocaust was further fuelled at the time of the Eichmann trial by the publication of Ben Hecht's Perfidy ${ }^{13}$, a book which detailed the KastnerGrünwald case and bitterly accused not just Kastner but Israeli leaders of betraying the Hungarian Jews for the sake of their elitist vision of a future Jewish state in Palestine. These allegations were later reiterated by Hannah Arendt in her book on the Eichmann trial ${ }^{14}$.

Numerous newspaper articles about Hecht's accusations, gathered with the typescript "Holokaust" in the Nachlaß, testify to the interest Hochwälder had in the events of the late 1950s and early 1960s. The issue of the position taken by Jewish leadership during the Holocaust has still not been laid to rest, as indicated by the statement made by Simon Wiesenthal as late as 1989:

For us [the Jewish people], too, there remains from the period of the Third Reich a part of history we have yet to come to terms with. No one else has a right to blame us for it - but we ourselves must face up to it some time. We have done very little to condemn Jewish collaboration with the Nazis ${ }^{15}$.

Both Bortenschlager ${ }^{16}$ and Murphy ${ }^{17}$ have observed that the central character of Holokaust is based on Rudolf Kastner, and the negotiations described in the play, in particular Rattengruber's suggestion that Jews might be traded for commodities (Holokaust, 54), clearly echoes Eichmann's infamous offer to trade Jewish lives for material to be used in the war effort. Glaser is also accused of many of the same crimes as Kastner: of failing to inform Jewish victims of their fate or encouraging them to resist, denying them the opportunity to escape or at least to attempt to defy their murderers (Holokaust, 50$)^{18}$; of betraying to the SS the parachutists who landed in Hungary

12 He was assassinated outside his home in March 1957.

13 Ben Hecht, Perfidy, (New York: Julian Messner, 1961).

14 Hannah Arendt, Eichmann in Jerusalem. A Report on the Banality of Evil, (London: Faber and Faber, 1963).

15 Simon Wiesenthal, Justice not Vengeance, Trans. Ewald Osers, (London: Mandarin, 1989), 271. Bauer's 1994 book Jews for Sale? also explores in detail Jewish negotiations with the Nazis.

16 Bortenschlager, Der Dramatiker Fritz Hochwälder, 147.

17 Murphy, 219

18 This allegation was made most strongly by Hecht, who claimed that without Jewish cooperation it would have been impossible to get the Jews to Auschwitz on schedule (Hecht, 95). The story of the fake mail from Jews already gassed to pacify those awaiting deportation is also based on historical evidence which incriminated Kastner (cf. Brenner, 260; Hecht, 100, 110 ). Whether or not the dissemination of information would have saved any of the Hungarian victims, or indeed whether the Hungarian Jews already had ample knowledge of the fate awaiting them, has been the subject of debate amongst historians (cf. Braham, 973, 996; Bauer, 105-107), but there can be no doubt that the Germans had no desire to risk another uprising like 
to carry out acts of sabotage (Holokaust, 64) ${ }^{19}$; of testifying after the war to save notorious war criminals (Holokaust, 68); and of personally selecting those to be saved, organizing, in his own words, the "Rettung einer Elite" (Holokaust, 54) ${ }^{20}$, while hundreds of thousands less fortunate went to their deaths.

This last charge was the most serious to be levelled at Kastner, and through him at the leaders of the young Israeli state, and is the central accusation in Hecht's account. They were, it is alleged, prepared to sacrifice the majority of the European Jews in order to preserve a select group of Zionists, upon which the new state of Israel might be founded. The concerns of those Jewish leaders best placed to help those facing annihilation were, according to this argument, criminally misplaced and aimed at preserving their own positions of power and influence, particularly in regard to the relationship which had been established with the British in Palestine.

The most damning evidence in support of the allegations comes from Eichmann himself, in transcripts recorded before he was kidnapped and brought to trial:

[...] Dr. Kastner was a young man about my age, an ice-cold lawyer and a fanatical Zionist. He agreed to help keep the Jews from resisting deportation and even keep order in the collection camps if I would close my eyes and let a few hundred or a few thousand young Jews emigrate illegally to Palestine. It was a good bargain [...] I believe that Kastner would have sacrificed a thousand or a hundred thousand of his blood to achieve his political goal. He was not interested in old Jews or those who had become assimilated into Hungarian society. But he was incredibly persistent in trying to save biologically valuable Jewish blood - that is human material that was capable of reproduction and hard work. "You can have the others", he would say, "but let me have this group here". And because Kastner rendered us a great service by helping keep the deportation camps peaceful, I would let his groups escape. After all, I was not concerned with small groups of a thousand or so Jews ${ }^{21}$.

that experienced in the Warsaw Ghetto, as Eichmann himself confirmed (Adolf Eichmann, "I Transported them to the Butcher", Life [Chicago], 28 Nov. 1961, 109). Hecht claims that the 20,000 Jews deported from Kastner's home town of Kluj would have had no trouble in overpowering the German guards watching them to flee across the nearby Rumanian border, but they were dissuaded from any such action by Kastner (Hecht, 101-104). Eichmann uses a similar argument in suggesting that the number of Jewish victims had been exaggerated, for had their numbers been so great, they could surely have organized effective resistance. (Eichmann, "I Transported them to the Butcher", 109).

${ }^{19}$ Brenner, 260-261, Hecht, 118-126. The suggestion that the parachutists may have been betrayed by Kastner is also made in Kipphardt's play, Joel Brand, 62, 66-68.

${ }^{20}$ Glaser's dealings with Polowny reflect Kastner's relationship with Kurt Becher. Kastner's testimony in favour of Becher in Nuremberg was crucial in absolving the SS officer from his crimes; cf. Braham, 970; Hecht, 70-82.

21 Adolf Eichmann, "To Sum it all up, I Regret Nothing", Life [Chicago], 5 Dec. 1961, 146. 
If having his efforts described in the racially loaded terms of Eichmann was not enough, his achievements paled into insignificance among the horrors of the mass deportations; brutally put into perspective by Hannah Arendt: "Dr. Kastner [...] saved exactly 1, 684 people with approximately 476,000 victims"22.

In fact, practicalities made it impossible to maintain selections based on highly questionable ideological considerations. For, while initially the selection of those to be saved was made on the basis of: "[those] who had distinguished themselves in Jewish public life; those who were in the service of the Jewish community or had made sacrifices for the advancement of Jewish welfare; and the widows and orphans of labor servicemen"23, this policy was soon altered. The pressing need for money to bribe corrupt Hungarian and German officials enabled wealthy Jews to buy their way to freedom, and safe passage was also arranged for various family members and friends of the Jewish council leaders, including Kastner's ${ }^{24}$. This in addition to the tacit validation of Nazi racial policies which such a selection policy signified ${ }^{25}$. But, while there are many similarities with the events in Holokaust and those that involved Kastner, there are several important differences which illuminate the dramatist's intentions, not least of which is the manner in which the above-mentioned accusations are effectively rebutted.

Firstly, this is not a highly publicised court case but a secret trial of the man Mister Roberts has been pursuing for about twelve years (Holokaust, 13), and, in part, it is for this reason that Glaser has knowingly walked into the trap laid for him: "In dieses Haus blickt die Welt nicht" (Holokaust, 36). Glaser, unlike Kastner, has not sought a prominent public position after the war $^{26}$, and in no way can he be linked to any government figures; indeed, as Roberts's long search shows, he has deliberately avoided the limelight and revealing what he knows, for it would have served no purpose: "Niemandem wäre gedient gewesen" (Holokaust, 36). This has the effect of removing the political content that was such a part of the historical events upon which the play is based.

The main allegations against Glaser are also discounted in Holokaust. He explains that resistance by the Jews was futile and limited to meaningless gesture ${ }^{27}$, that flight was impossible since they were surrounded by hostile nations, and that when he tried to tell the Jews what awaited them they refused to believe him, with even his own uncle denouncing him: "Hört nicht auf ihn, er predigt, der Herr läßt zu, daß seine heilige Gemeinde, die soviel Gutes getan

22 Arendt, 105.

23 Braham, 953. The similarity to the criteria used by Glaser is striking [see below].

24 Cf. Brenner, 259; Braham, 956.

25 Arendt, 117, Braham, 976.

26 Significantly, the play takes place in France, not Israel.

27 Mention of the uprising in the Warsaw Ghetto, which was ultimately crushed by the Nazis, is conspicuous by its absence. 
und den Armen geholfen hat, ausgerottet werden soll - hört ihn und seine Ratschläge nicht an, er ist ein gottloser Verräter" (Holokaust, 53$)^{28}$. Glaser's claim that negotiations with the SS was the only option open to him: "Es blieb kein anderer Weg, um wenige zu retten" (Holokaust, 50), is not challenged by the presentation of viable alternatives, unlike in the case of Rudolf Kastner.

Glaser is also able to explain adequately the betrayal of the parachutists: the saboteurs arrived far too late to stop the main deportations, but Jechiel's insistence on carrying out their orders to blow up the railway station did endanger Glaser's efforts to save the few for whom he had bargained. The death of the two other parachutists was an unforeseen tragedy caused by his partner in the SS, Powolny, being unexpectedly called away (Holokaust, 65-67). It is for the same reason, to save the few he could, that he testified in Powolny's favour after the war in Nuremberg: "[...] die Raison kümmerte mich nicht, faktisch hatte er mehr zur Rettung von Tausenden beigetragen als Silly Bollag in der Schweiz" (Holokaust, 68).

Finally, the issue of the selection of those to be saved, the "Rettung einer Elite", differs from the events involving Kastner. Similar criteria as those originally intended by the historical figure are employed, but in Glaser's case these were adhered to, and there is no suggestion that family and friends were favoured:

Eins blieb unabdingbar: die Auswahl durfte nicht nach Zahlungsfähigkeit erfolgen, die Wertvollen sollten gerettet werden, nicht die Reichen [...] Man redete mir ein, ich sei verpflichtet, heilige Grundsätze anzuwenden [...] hätte vor allem jene zu retten, die ihr Leben der Gemeinschaft widmeten; sodann weltfremde Gelehrte; Frauen, deren Männer im Arbeitsdienst umgekommen waren; Kinder, Waisen [...] ich setzte Menschen auf die Liste, die nicht untergehen durften, Gelehrte, unbeholfen, bettelarm, dem Geist ergeben, der unersetzlich ist [...]

(Holokaust, 57-58)

Glaser's determination to stick to this is made clear by the account of Elemer Klein, who, despite being an acquaintance and raising a large sum of money with which to buy passage to safety, is not included on the list. Glaser's selection policy remains morally questionable [see below], but by having his protagonist adhere to it strictly, Hochwälder avoids the issues of nepotism and corruption raised in the Kastner case. Glaser was in an impossible position, forced to make terrible choices, but these choices were not made for personal gain. So convincing is his portrayal of events that his would-be judge, Roberts, must concede that in similar circumstances he would have acted the same way (Holokaust, 79, 85).

In addition to the fact that Glaser effectively refutes the main allegations

28 A similar tale is told by Hansi Brand in Kipphardt's play; this time the words are her father's: "Hört nicht auf diese Frau, sie ist eine Gotteslästerin. Sie sagt, daß Gott es zulassen wird, unsere heilige Gemeinde, die nur Gutes getan hat, auszurotten. Hört sie nicht an" (Joel Brand, 19). 
against him or justifies his actions, the "trial" also reveals the dubious behaviour of his main accusers. As Hochwälder demonstrated in the earlier plays, Esther, "Casa Speranza" and Hôtel du Commerce, persecution does not ennoble its victims, and so it is in Holokaust: Elemer Klein, for example, is dominated by self-interest and greed. His love of money not only colours his behaviour but also the way he views the past. Having established a publishing house at the end of the war, he has made good capital from the Glaser story (Holokaust, 10-11), and he clearly views Glaser's greatest crime as stealing the money he raised to save himself (Holokaust, 11). It is the promise of regaining this wealth that encourages him to stay when pecuniary interests make him anxious to leave (Holokaust, 14-17). Yet the money in question, taken by Glaser to save the more worthy in the belief that Elemer would be cunning enough to survive anyway, (Holokaust, 58 ) was acquired by Elemer in a scarcely honourable manner from his fellow Holocaust victims, as becomes apparent under cross-examination by Roberts:

ELEMER: [...] nicht mich - weist auf Glaser - jenen haben sie zu verhören.

ROBERTS: Antworten Sie: welche Mittel setzten Sie ein, um der Vernichtung zu entrinnen?

ELEMER: Was kümmert es Sie, bin ich der Angeklagte?

ROBERTS: Mir dämmert manches, nach und nach... Hand aufs Herz Elemer: Wen haben Sie beraubt, erpreßt, verraten?

ELEMER in hellem Zorn: Was reden Sie, was wissen Sie, ahnungsloser Westler, der Sie sind - hat man Sie verfolgt, im Viehwaggon verfrachtet, waren Sie jemals vom Gas bedroht? - die Flucht davor rechtfertigt jedes Mittel.

GLASER: Bravo, Kamerad.

ELEMER: Du schweig. - Ich hab genug bis an den Hals, gib mir mein Geld zurück, ich gehe.

(Holokaust, 58-59)

Despite such revelations Elemer remains unrepentant, and even dreams up a grotesque scheme to make further capital from Glaser with the help of Jechiel, who is still bent on revenge:

Sie denken nach wie vor fallschirmerisch, das war gut im Krieg, in Friedenszeiten liegen die Dinge anders, auf Mord steht hierzulande Madame Guillotine, die ominöse Witwe, höhere Gerechtigkeit bleibt den Geschworenen im allgemeinen fremd, vielleicht kommen Sie mit Lebenslänglich davon - lohnt sich das? [...] Mein Plan: Sie spüren dem Verschwundenen [Glaser] nach, setzen ihn aufs Neue fest - das ist ein Auftrag, bitte sehr -, dann zwingen Sie ihn, wenn nötig mit Brachialgewalt, Memoiren zu verfassen, die er mir zur Exklusivauswertung überläßt, tantiemenfrei, versteht sich; das wird ein Bucherfolg, sage ich Ihnen, jeder General muß vor Neid erblassen: Übersetzungsrechte, Filmverkauf

(Holokaust, 76-77) 
But, while Jechiel angrily and violently rejects such a proposal, his own role during the war is not above reproach, despite the manner in which he suffered at the hands of the Nazis (Holokaust, 18-19) ${ }^{29}$. The fact that he is not an entirely innocent victim becomes apparent when he is questioned by Roberts, and it is revealed that although his mission was futile, and could only endanger those Glaser hoped to save, he made the fateful decision, like other Hochwälder characters before him [see chapter 4], to follow orders (Holokaust, 65-66).

The exposure of this fundamental weakness in Jechiel's character, the need to follow orders rather than confront moral dilemmas alone, ultimately dissuades Jechiel from seeking revenge. When Roberts admits that in the same circumstances he would have acted like Glaser, Jechiel turns on him with the revolver, only to have his resolve shattered by Roberts's insightful observation: "Sie wagen es nicht, Jechiel. Kein Auftrag, kein Befehl, der Sie deckt: Im Grunde sind Sie feig wie so manche Kriegshelden" (Holokaust, 79-80) ${ }^{30}$.

The other witness to testify against Glaser, the inarticulate, uncommunicative, "Polizistentyp", Berek, (Holokaust, 11) has the darkest past of all and is also conditioned to take orders, earlier from his Nazi masters and now from Mister Roberts; the first word he utters is "Befehl" (Holokaust, 12). The full truth of his terrible crime is not revealed to the other characters, and is only alluded to by Glaser when he suggests that Roberts, were he in Berek's position as a ghetto policeman under pain of death to deliver a quota of deportees, would have sacrificed his own parents to save his own life (Holokaust, 62). It is the knowledge that this is in fact what happened that Glaser uses to force Berek to deliver the "Freispruch" or death sentence he seeks:

GLASER: [...] Wie, wenn ich stracks zur Schwester ginge und ihr erzählte, daß du zuletzt laut heulend deine alten Eltern zur Deportation schlepptest -

BEREK in Tränen: Nein, Herr, das werdet Ihr nicht tun... Ihr tut es nicht, schwört, schwört. Auf den Knieen: Der Kommandant hat uns gezwungen, mit der Peitsche... ich... wollte nicht ... wollte nicht sterben... die Eltern... alt, verhungert, krank... kaum einige Tage hätten sie gelebt... sie folgten willig zu den Gleisen, Hand in Hand $[\ldots]$

(Holokaust, 89)

With the behaviour of the final witness thus exposed, the questions about Glaser's actions have been answered, at least to Roberts's satisfaction, and the conduct of all his accusers has been challenged. Yet despite this, Glaser is insistent that his accusers should not be judged guilty, for they were acting under exceptional and horrifying circumstances: Elemer and Berek did what

29 The manner in which Jechiel escaped the Nazis, by leaping from a train, is similar to the manner in which the Zionist parachutist into Hungary, Joel Palgi, managed to escape and survive. Cf. Hecht, 125.

30 Handwritten annotations render the following changes: "Sie wagen es nicht. Kein Auftra [sic], kein Befehl, der Sie deckt: Sie sind im Grunde feig, wie die meisten Kriegshelden". 
anyone else, including Roberts, would have done in their place in order to survive (Holokaust, 60); while Jechiel cannot be blamed because Glaser did nothing to refute the reputation for treachery he had acquired, concentrating solely on saving the two thousand (Holokaust, 67). Even after Berek has shot Glaser, Glaser with his dying breath is insistent that nothing should happen to his assassin (Holokaust, 91).

Notwithstanding being able to dismiss both accusations and accusers, Glaser is not interested in defending his actions, only with explaining what happened, a point he makes clear at the outset of the trial (Holokaust, 47). The "Freispruch" he seeks is not what it initially seems, but the release from a troublesome conscience; as Roberts partly suspects: "Gibt es einen Freispruch, der da lautet: 'Tod'?" (Holokaust, 43). When for a moment Glaser lets the mask slip in the first scene in which he appears, it is clear that he is a man plagued by his past:

Wer mit dem Teufel speist, muß einen langen Löffel haben; das hatte ich nicht bedacht, was für ein Wahn, welche Verblendung. Als mir die Augen aufgingen, war es zu spät; der Holokaust, das Brandopfer war vollzogen, ich kehrte zu den Lebenden zurück, was für ein Jammer, welches Ver hängnis...

(Holokaust, 35)

The true nature of the guilt and burden he has taken upon himself only becomes apparent through his interaction with Mister Roberts; as Jechiel observes when leaving (Holokaust, 80), the two have much in common ${ }^{31}$ : both make the arrogant assumption that they have the right to sit in judgement on others, an arrogance born of a lack of faith in God and humanity. However, there is one significant difference between them: Glaser has submitted himself to trial ready to accept the full burden of responsibility for his actions, while Roberts shows himself to be unprepared to take on the full ramifications of his self-appointed task.

The presumptuousness of Roberts's undertaking is made clear very early in the play:

Ich zermarterte mein Gehirn: Wie locke ich Gott aus den Finsternissen? [...] Als ich dieses Buch gelesen hatte - "Victor Glaser, le traitre juif" wußte ich Antwort: Geh und setz den ererbten Reichtum ein, verwandle ihn in Macht, spür den Verräter aus, verhör und straf ihn, wie es ihm gebührt - so zwingst du den Gerechten in eine glaubenslose Welt zurüick: Es werde Recht!

(Holokaust, 16)

The monstrous presumption that single-handedly he might bring faith back

31 The similarity between the two men was originally emphasized even more by Glaser in the typescript, in text subsequently struck out by hand: "Ich wusste von Anfang, dass Sie meinem Wesen in sonderbarer Weise gleichen - dieses Wesen führt mich zurück, hierher, wohlverstanden: ausschliesslich zu Ihnen" (Fritz Hochwälder, "Holokaust. Schauspiel in drei Akten", ts., 1961, Hochwälder Nachlaß, Wiener Stadt- und Landesbibliothek, Wien, p. 75). 
into the world, has much to do with his own inadequacies, for in many ways Roberts has much in common with the figure Pomfrit from Donnerstag, and is seeking meaning to his life, which until this point has been "ohne Aufgabe, ohne Glauben, ohne Gott" (Holokaust, 16). But his doubts about the existence of God are far from laid to rest by his actions (Holokaust, 65), and at the end, like previous Hochwälder characters [see chapter 3], he abdicates the responsibility he had earlier been eager to take on, choosing to flee rather than carry out the sentence Glaser demands (Holokaust, 88).

Such pessimism and loss of faith in God and humanity are also apparent in Glaser's attitude, and are clear in the cynicism with which he explains to Rouzha why she should not trust him:

Weil niemand keinem etwas glaubt, zumeist mit gutem Grund. Die Ereignisse, die Menschen - ein blutiger Karneval, maskierte Strolche, schreckhaft und lächerlich zugleich. Einzig im Gedicht wohnt Wahrheit, selbst Grauen nimmt Form des unvergänglich Schönen an, lesen Sie Baudelaire [...]

(Holokaust, 28)

He has had enough of living with his own past and the knowledge of how far humanity can sink: "[...] man will gefangen werden, will das Ende - man will es und man weiß es" (Holokaust, 34). The burden he bears has left him isolated and dehumanized, as he reveals to a perplexed Roberts who cannot understand his cavalier attitude to being caught:

ROBERTS konsterniert: Ja - - sind Sie noch - ein Mensch?

GLASER plötzlich ernst: Längst nicht mehr, Mister Roberts.

(Holokaust, 37)

Such experiences have led to a pessimistic outlook which, similar to opinions voiced in Lazaretti oder Der Säbeltiger [see chapter 7], sees no future for a human race motivated not by love but by hatred of itself:

Selbsthaß. - Das gehorchte unwissentlich, unwillentlich dem furchtbaren Gebot: "Hasse deinen Nächsten wie dich selbst." - Nichts Neues übrigens. Luther, als er das Tintenfaß nach dem Teufel warf, hatte an der Wand gewiß den eigenen Schatten gesehen... so wäre der Holokaust lediglich Generalprobe zur radikalen Selbstvernichtung gewesen [...] (Holokaust, 69)

But such a nihilistic view of life does not excuse his own role in the destruction that took place under the Nazis, for he played his part in the Holocaust voluntarily, unlike his accusers who were literally fighting for their lives:

Wir kommen zur Person. - Wer drängte sich freiwillig, ohne Folterzwang, zu dieser Aufgabe? - Ein Elender, ein Glaubensloser, er einzig und allein, dessen Herz von Verachtung erfüllt war für die Herde frommer Dulder, die 
However, the events under examination have wider ramifications than merely the fate of the individual Glaser, for as he warned Roberts earlier: "Es geht um jeden, der Menschenantlitz trägt" (Holokaust, 52). In a reversal of roles in the final act Glaser makes clear to the man who would have done as he did, just what the significance of such a claim is:

GLASER: Sie gestehen: was ich tat, hätten Sie ebenfalls verübt. Korrekt?

ROBERTS: Durchaus.

GLASER: Sie wohnten hier als Hoher Richter. Nun steht mir gleiches zu.

Roberts stumm.

GLASER wandert: Demnach beschuldige ich Sie: einen Teil der Macht über die organisierte Hölle an sich gerissen zu haben, mit leeren Händen - nicht um das eigene Leben zu retten, dies bleibt jederzeit verzeihlich - nein: selbstlos, scharfsinnig, den Bürokratenbestien turmhoch überlegen; um über Vernichtung oder Davonkommen anderer zu befinden; aus Hochmut, Ehrgeiz, Überheblichkeit, Verblendung (Holokaust, 86)

Repeating his earlier sentiments: "wer mit dem Teufel speist, muß einen langen Löffel haben" (Holokaust, 86), he goes on to show that through his actions he in fact sanctioned the selection policies of the Nazis:

Ich zeige auf, was Sie zu diesem Amt trieb, verhüllt von den Schwaden unserer Fehlgeschichte: Der Heilsplan Mister Darwins, die Auslese der Tüchtigen, das Programm des Rassehauptamtes SS - der Satansplan der Gegner wurde vollends zu dem Ihren, unwissentlich, unwillentlich, dennoch höchst wirksam: ungleiche Kappen, gleiche Brüder - jeder Name, auf die Rettungsliste gesetzt, bedeutete Verderben für den Nichtgenannten, wer war lebenswert, wer todeswürdig, wem steht solche Entscheidung zu, Ihnen vielleicht, Mister Roberts?

(Holokaust, 86-87)

Roberts's desperate attempts to defend Glaser's actions are rejected by Glaser; there can be no compromise with evil: "verflucht das kleinere Übel, das ungeheuere Schuld erst möglich machte", and even if it had been the only way there is no escaping the terrible ramifications of such a course of action: "Mag sein, daß getan werden mußte, was geschah; doch jener, der solcherweise handelnd sein Menschtum schändete" (Holokaust, 87). Unlike those that committed crimes in a desperate effort to save themselves, Glaser voluntarily chose to compromise with the forces of destruction, and in doing so allowed himself to become their tool, sacrificing his own humanity in the process. Confronted by Glaser's unrelenting exposure of the repercussions of what took place, Roberts finally concedes that the only sentence that can be passed is 
death. However, he is not prepared to carry this judgement out: "Dieser Freispruch - tötet mich". He now chooses to run, rather than accept responsibility as judge, proving to be, in Glaser's words, an "Erzverräter" (Holokaust, 88). Glaser is left to provoke Berek into carrying out the sentence he has sought from the outset (Holokaust, 88-90).

The play, Hochwälder's first direct confrontation with the Nazi past, paints an almost unremitting picture of despair about human nature. The nihilistic views of Glaser would seem to be borne out by the behaviour of his accusers, who have done terrible things to preserve their own lives. Roberts demonstrates that the arrogance of Glaser and the Nazis who chose to sit in judgement on the fate of others, may at any time be repeated by the like-minded who feel the moral imperative to behave like gods. Glaser seeks release in death, Roberts chooses to run. Yet two characters do offer some slight hope for humanity, and in typical Hochwälder fashion, this role fall to the female figures of Mme. Singer and Rouzha ${ }^{32}$.

Singer represents human decency, and despite all she has experienced has maintained her faith in her fellow humans; she is herself a witness to the good that can be done, having been kept in safety during the war in France by simple peasants (Holokaust, 45). It is not surprising then that she does not get on with the self-serving Elemer, which is apparent from the opening scene (Holokaust, 9-11), and that she is taken aback by Jechiel's apparent brutality (Holokaust, 19). Her suspicions of the others are confirmed by the events that unfold during the trial, and thereafter she rejects outright the behaviour of Berek, Elemer and Jechiel (Holokaust, 73-76). She also struggles to keep up the deception planned for Glaser (Holokaust, 32), and after meeting him she is convinced he is innocent of the charges brought against him: "So wahr Gott lebt: dieser Mann ist unschuldig" (Holokaust, 45) ${ }^{33}$.

The character Rouzha has a particularly important role at the end of the play. Her relationship to Roberts, that of a younger woman with a much older man, has much in common with those seen in the plays, "Casa Speranza", between Lilli and Faden, and Lazaretti oder Der Säbeltiger, between the character of the same name and Camenisch. As in those plays, an unhealthy co-dependency has developed (Holokaust, 22) through which the characters try to alleviate their personal isolation and loneliness, only for the relationship to be ultimately broken when the female character rejects the attitudes of her older companion.

From the outset, Rouzha feels uncomfortable with the deception she is involved in and must be reassured by Roberts (Holokaust, 21). Later she again questions what they are doing:

32 It will not escape notice that a character of the same name fulfils a similar function in Lazaretti oder Der Säbeltiger, a play which also raises the question of whether humanity, by its very nature, is doomed to self-destruction.

33 It is significant that she chooses to express this with reference to a faith that both Glaser and Robert have lost. 
ROUZHA: Ist Ihr Ziel nach wie vor: Recht und Gerechtigkeit?

ROBERTS: Sie zweifeln?

ROUZHA: Der Weg ist gefährlich: Sie werfen sich zum Richter auf.

ROBERTS: Seit wann solche Bedenken?

ROUZHA: Seit - dieser Mann hier ist.

(Holokaust, 46) $)^{34}$

That she, like Singer, shares a growing sympathy for Glaser is shown when she worries about the wound he has received from Berek (Holokaust, 60), and significantly it is the women who come to his aid when he is dying (Holokaust, 90-91). By this stage Rouzha has rejected Roberts and intends to stand by Glaser, having seen that Roberts is really motivated by self-interest: "Ich sehe: Sie wollen sich helfen. [...] Sie denken wie Sie dachten: verkappt immer ans eigene Elend" (Holokaust, 83).

This decision to "sacrifice" her life to Glaser (Holokaust, 83) takes a twist in the dramatic closing scene. As Glaser dies, praying, in the manner of Pomfrit in Donnerstag, to a god in whom he does not believe, and as Singer insists that they must continue to hope, despite all that has happened: "Anders verdienten wir nicht, zu atmen", Rouzha makes the decision to turn herself in to the police as Glaser's murderer, and in doing so, Christ-like, she bears witness to and takes on the sins of others (Holokaust, 91).

This melodramatic ending is the play's main weakness: Rouzha's saint-like behaviour and motivation, like so many of Hochwälder's female figures, remains unsatisfactory. Likewise, Glaser's elaborate efforts to end his own life also stretch credibility. Nevertheless, the play explores fascinating and complex problems, and further demonstrates concerns seen in earlier Hochwälder plays.

The first play dealing with the Nazi legacy to be published and performed was Der Himbeerpflücker. This savage, satirical attack on former Nazis living respectable lives in the democratic Second Republic, while all the time harbouring a yearning for the good old days under Hitler, owes much to Gogol's The Government Inspector: both plays employ a case of mistaken identity to explore a corrupt society. However, in Hochwälder's play there is no suggestion at the end that the population of Bad Brauning is about to be brought to task. As Daviau points out, it also has much in common with Hochwälder earlier comedy, Der Unschuldige, in that it explores guilt that may lie beneath the surface of respectability ${ }^{35}$, although in the case of his Nazi satire, the past is scarcely buried.

Hochwälder himself devoted some considerable space to the play in his essay, "Über mein Theater", in which he emphasizes that the play is far from an exaggeration:

\footnotetext{
34 In a passage in the typescript, which hand corrections suggest was to be deleted and which does not exist in the printed version, she also struggles to continue typing the transcript of the trial, finding the whole procedure "unmenschlich" ("Holokaust", 44).

35 Daviau, "Fritz Hochwälder", 257.
} 
Der Himbeerpflücker, der sich als Komödie bezeichnet, naturgemäß jedoch als Schwank, ja als Posse daherkommt, behandelt ein auf den ersten Blick erstaunliches Faktum österreichischer Gegenwart: die unbekümmert fröhliche Urständ feiernde Nazigesinnung in der Zweiten Republik. - Als einer, der seine Pappenheimer nicht erst seit gestern kennt, bin ich außerstande, darob entsetzt die Hände über den Kopf zusammenzuschlagen; was sich da ereignet, ist leicht erklärlich, sofern man sich entschließt, die von Berufspolitikern offerierten schwarzen Scheuklappen zurückzuweisen $^{36}$, ganz zu schweigen vom materialistischen Erklärungsversuch der Vulgärmarxisten, diesen Scholastikern unseres Jahrhunderts. Der alpenländische Nazismus österreichischer Provenienz, der Ur-Nazismus demnach, war und ist keineswegs, als was man ihn unentwegt hinzustellen beliebt: das Werk einiger Volksverderber und Rattenfänger, die sich Elend und Vezweiflung zunutze machten. - In Wirklichkeit entspringt der ungebrochene faule Zauber der unstillbaren Sehnsucht jener vielen, die nie, nie wieder ihr eigenes Abbild so erfolgreich gesteigert sehen werden wie es in vergangener Blutzeit geschah: in Person eines ihnen aus Visage und Wesen geschnittenen, verkorksten und vestunkenen Troglodytenführers, einer miserablen Schwank- und Possenfigur, der ums Haar gelungen wäre, wovon man in Bad Brauning träumt: die Welt der eigenen Minderwertigkeit zu unterwerfen. Wahrlich, "der Schoß ist fruchtbar noch, aus dem das kroch". - Da liegt der Hund begraben, und genau da setzt meine Komödie ein, die leider keine Erfindung, sondern Reportage ist, vielfach abgeschwächt und gemildert allerdings, auf daß sich einige Glaubwürdigkeit einstelle ${ }^{37}$.

Events in Austria [see above] continued to add weight to such claims, as public attitudes to the Nazi past remained, at best, ambivalent; Hochwälder observed in 1965 to Ernst Waldinger, the television production of Josef Roth's Radetzkymarsch could cause a scandal because of its portrayal of Franz Josef, while the fact that a journalist from Forum could openly collect money on the streets of Vienna for the war criminal Franz Novak caused barely a stir ${ }^{38}$. Fortuitous, or perhaps considering the gravity of what was being exposed, unfortunate incidents, also highlighted the continuing validity of the play in later revivals: in 1975 it was performed in Linz while the controversy surrounding Wiesenthal's exposé of the Nazi past of Friedrich Peter, leader of the FPÖ, was earning the ire of Bruno Kreisky ${ }^{39}$; and in 1986 it was staged at

36 Here, Hochwälder may be aiming a barb at Bundeskanzler Klaus, who, making use of what Hochwälder described as a politician's "Lügnerrecht", attempted to portray to the world cases of Austrian anti-Semitism as exceptions rather than the rule, cf. Fritz Hochwälder, Brief an Ernst Waldinger, 7. Juni 1966, Dokumentationsstelle für neuere österreichische Literatur, Wien. 37 Hochwälder, Im Wechsel der Zeit, 99-100.

38 Fritz Hochwälder, Brief an Ernst Waldinger, 21. Mai 1965, Dokumentationsstelle für neuere österreichische Literatur, Wien. Cf. Oscar Bronner, "Bitte eine Spende für Novak", FORVM, XII (1965), 134.

39 For Wiesenthal's version of this incredible affair, which resurfaced in Austrian politics in 
the Volkstheater in Vienna while Kurt Waldheim's memory lapses about his war-time record were holding world attention.

In spite of this it is striking how often Austrian critics attempted to label the play dated and argue that it was either no longer relevant, or simply an inaccurate portrayal ${ }^{40}$, often in rather disturbing terms. Erich Thanner, for example, spends most of what is ostensibly a review of the play defending Austria's honour against Hochwälder's attack:

[...] hier, im Himbeerpflücker, ging der Wahrheits- und Gerechtigkeitssucher Hochwälder an Wahrheit und Gerechtigkeit vorbei. Der Ansatz war falsch. Ein österreichisches Provinznest, das ausschließlich von stumpfsinnig fanatisierten Nazis bevölkert war und ist - das gab und gibt es schlichtweg nicht ${ }^{41}$.

He goes on to provide a long list of examples of those that resisted the Nazis in a country seen as just another victim of German aggression: "Es gab ihrer in Österreich wahrhaftig nicht weniger als in irgendeinem anderen von Hitler besetzten Land".

Josef Laßl feels equally uncomfortable with a play that rakes over a past best left alone, and sees the Peter affair as a negative influence on the production:

Die Aufführung der Komödie [...] litt trotz guter schauspielerischer Leistungen unter den innenpolitischen Machenschaften des Nazi-Jägers Simon Wiesenthal, der mit seinen Verdächtigungen gegen einen österreichischen Abgeordneten wieder die Schatten der Vergangenheit rief [surely the object of the play!]. Die Zuschauer im Theater schienen von den Bühnenvorgängen irritiert, weil sie sich plötzlich, entgegen dem possenhaften Einschlag des Stückes, noch der Wirklichkeit vor einem Menschenalter gegenübergestellt sahen ${ }^{42}$.

Laßl goes on to make the rather incredible statement: "Die Ambivalenz des österreichischen Wesens, besonders was den Antisemitismus und die Konzentrationslager betrifft, kann auch literarisch nicht nur mit den Augen eines Juden

1983 see Justice not Vengeance, 344-356. For an outsider's account of the rather incredible Austrian ability for amnesia and insensitivity regarding the Nazi past, albeit somewhat journalistic in its approach, see: Richard Bassett, Waldheim and Austria, (London: Viking, 1988).

40 Sonvico, "Himbeeren mit Würmern darinnen", Tagblatt [Linz], 13. Okt. 1975; H. Sch., "Auf den Unterhaltungswert reduziert", Salzburger Nachrichten, 13. Okt. 1975; Erich Thanner, "Kein Antitheater", Die Furche [Wien], 25. Okt. 1975; abs., "Über die alten Nazileut", Welser Zeitung, 6. Nov. 1975; Gunther Martin, "Herr Karl im NS-Schilda", Wiener Zeitung, 5. Jan. 1985, 4; Renate Wagner, "Eine unreinliche Mischung", Neues Volksblatt [Linz], 5. Jan. 1985; Ludwig Plakolb, "Brauner Dreck am alten Stecken", Oberösterreichische Nachrichten [Linz], 24. März 1986, 10; Gunther Martin, "Panoptikum der 'alten Kämpfer"', Wiener Zeitung, 25. März 1986, 4.

41 Erich Thanner, "Kein Antitheater", Die Furche [Wien], 25. Okt. 1975.

42 Josef Laßl, "Ein literarischer Simon Wiesenthal", Oberösterreichische Nachrichten [Linz], 13. Okt. 1975. 
und Emigranten gesehen werden. Der Himbeerpflücker ist ein mißlungenes Volksstuick [...]". The play might have been more palatable if it had been written by a resident Austrian who was not biased by losing relatives in the concentration camps.

Gunther Martin, writing for the Wiener Zeitung in the 1980s, also faced difficulties caused by political events bestowing an uncomfortable relevance on the play. When the play was taken through the Außenbezirke in 1985 he was able to dismiss it as a reasonable play in its day, namely the mid-1960s, but one that had lost its relevance with the passing of time: "Wir stehen heute vor völlig anderen brennenden Fragen, und wie gut wäre es, würde sich eine Potenz wie der lebens- und weltkluge, ergo skeptische und pessimistische Fritz Hochwälder mit der gleichen Ausssagekraft solchen Problemen zuwenden $[\ldots] " 43$. A year later, however, when the play was transferred to the main house of the Volkstheater, and when the Waldheim controversy was raging, the same reviewer found the play to be nonsense:

$\mathrm{Da}$ irgendwann und irgendwo in Österreich seit 1945 ein Dorfhonoratior seinen alten braunen Uniformrock aus der Rumpelkammer geholt und die Gaststube mit Hakenkreuzfahne und Hitler-Porträt dekoriert hätte, ist ebenso absurd wie dieses ganze NS-Schilda ${ }^{44}$.

Furthermore, the suggestion, implicit in Laßl's remarks, of a foreign axe to grind is also made: "Angesichts solcher Karikaturen fühlt man sich oft ins agitatorische Disneyland amerikanischer Propagandafilme aus der Kriegszeit versetzt". This is a far cry from Martin's 1985 description of a play "voller dankbarer, lebendiger Rollen, gut und zügig spielbar und zum Zeitpunkt der Entstehung aktuell"45.

Others found the play's subject matter inappropriate for the genre of the Volksstück and comedy ${ }^{46}$. But, as Holdman has observed: "[...] Hochwälder has avoided the direct presentation of atrocity which stuns reason and diminishes the facility of weighing the significance of appalling social disorder" ${ }^{\prime 4}$, and considering his attacks are aimed at those with Nazi sentiments holding down respectable positions in the new Austria, whom he viewed with considerable scorn, ridicule is an entirely appropriate register. One need look no further than Simon Wiesenthal, who perhaps more than anyone else has devoted himself to exposing the horrors of the Nazi past, for affir-

43 Gunther Martin, "Herr Karl im NS-Schilda", Wiener Zeitung, 5. Jan. 1985, 4.

44 Gunther Martin, "Panoptikum der 'alten Kämpfer”, Wiener Zeitung, 25. März 1986, 4.

45 Wiener Zeitung, 5. Jan. 1985, 4.

${ }^{46}$ Renate Wagner, "Eine unreinliche Mischung", Neues Volksblatt [Linz], 5. Jan. 1985; Otto Hochreiter, "Ein obszönes Theater", Die Presse [Wien], 24. März 1986, 6; Viktor Reimann, "Das Gelächter des Todes", Neue Kronen Zeitung [Wien], 24. März 1986, 16.

${ }^{47}$ Holdman, 93. To this can be added the observation of Theodor Adorno: "Vollends jenseits der Möglichkeit von Realismus ist das Grauen der Hitlerwelt" - Theodor W. Adorno, "Reflexion über das Volksstück (zu Fritz Hochwälders Himbeerpflücker)", Der Befehl, von Fritz Hochwälder, (Graz: Stiasny, 1967), 109. 
Humour [...] should sometimes be deliberately employed as a weapon: the neo-Nazis are best fought by making them look ridiculous. It should even be possible, in retrospect, to make figures like Hitler and Himmler objects not only of revulsion but also of ridicule. I cannot think of anything more ridiculous than that moustachioed Germanic dwarf with his tinted hair, who barked his speeches like a seal and then, like a string puppet, flung up his arm awkwardly and crookedly in the Hitler salute. One cannot nowadays watch film clips of his big speeches without laughing. Or stand amazed at the fact that this half-crazed, half-educated petit bourgeois actually managed to fascinate millions. This was probably due to the fact that, during his earlier speeches, people had far too rarely stood up to make him look ridiculous by a skilful counter-question. At least in dealing with the neo-Nazis we should, in my opinion, apply this recipe of ridicule every time ${ }^{48}$.

A precedent for Hochwälder's approach in portraying opportunistic old Nazis had, of course, already been set in 1961 with the broadcast of the dramatic monologue, Der Herr Karl ${ }^{49}$, starring Helmut Qualtinger, whom Hochwälder had always envisaged in the role of Steisshäupt ${ }^{50}$, and who subsequently starred in the television broadcast of the play on 9 April 1965. Indeed, Hochwälder claimed some credit for influencing Qualtinger's portrayal of Herrn Karl through the character of Wondrak in Donnerstag ${ }^{5 !}$.

That ridicule is at the heart of Hochwälder's intentions is clear from the setting of the play: an inn, ironically named "Zum Weißen Lamm", in the Provinznest Bad Brauning, a name which manages to suggest both Hitler's birthplace of Braunau and the Nazis' trademark colour brown. It is evident from the opening scenes that old Nazi sentiments still linger, with barely an effort to disguise them, despite the insistence by the ludicrously named Sieglinde ${ }^{52}$ : "Wir leben in einer neuen Zeit" (II, 213). The first conversation between Schnopf and Huett prophetically belies this:

HUETT: Was Neues?

48 Wiesenthal, Justice not Vengeance, 406-407.

49 Helmut Qualtinger und Carl Merz, Der Herr Karl, 1959, In: Der Herr Karl und weiteres Heiteres, von Qualtinger und Merz, (Reinbek bei Hamburg: Rowohlt, 1964), 5-31.

50 Brief an Ernst Waldinger, 24. Aug. 1965, Dokumentationsstelle für neuere österreichische Literatur, Wien.

51 Hochwälder, Im Wechsel der Zeit, 97.

52 As her father tells her, the Wagnerian overtones of her name are no accident: "Wir haben dich nicht umsonst Sieglinde genannt, man hat damals gehofft aus heißem Herzen - und dann war alles aus, ein Traum aus. Blut und Treue ..." (II, 232). Indeed the names of the characters are very evocative, as Holdman [101] has noted: for example there is Kerz, who casts light on the true nature of Bad Brauning; the builder, Ybbsgruber; the brow-beaten, Zagl; and the delightfully named Steisshäuptl. 
SCHNOPF: Einbruch in Ganselstadt, beim Juwelier Rosenberg.

HUETT: Ein Jud.

SCHNOPF: Nein, Balte, ursprünglich. (Vertraulich:) Wie unser Rosenberg ${ }^{53}$.

HUETT verträumt: Ach, unser Rosenberg... [...] Letzten Endes kommt alles von der sinnlosen Zerstörung der gesetzten Vorbilder, die einem gesunden Volk erwachsen, zu unserer Zeit hat man gewußt, wie man mit diesem Gesindel fertig wird, Kopf ab entweder oder ins $\mathrm{KZ}$, es gibt nur klare Lösungen - sind Sie nicht auch der Ansicht, Herr Doktor?

SCHNOPF: Was wollen Sie, die Zeiten sind vorbei.

HUETT: Alles kehrt wieder.

SCHNOPF: Eine Illusion.

HUETT: Kleinmut ist fehl am Platz, wir bleiben, die wir waren. (II, 214)

Ybbsgruber's arrival confirms how little attitudes have changed: he is greeted as "Herr Oberstleutnant", to which he responds with a "Heil" (II, 215). It is he, through an article in his "Kameradschaftszeitung", who raises the possibility that they may be called on to help "einen von denen, die jetzt vor alttestamentarischer Rachsucht flüchten müssen" (II, 216). The prospect of being called on to help a former comrade is the excuse for an absurd revisionist view of history, which paints the Germans as the victims of racial persecution and suggests that the war was not, in fact, lost:

HUETT: ... Psychopath, Schinder, Sadist - was noch, Herr Doktor? (Richtet sich auf.) Und was wäre geschehen, wenn man mit uns nach Lust und Laune hätte umspringen können, ich meine: wenn Roosevelt nicht rechtzeitig als Kommunist entlarvt worden wäre? [...] Man hätte uns in ferne, unwirtliche Gefilde verschleppt, nach Rußland und Amerika, niemand wäre verschont geblieben, die heimatliche Erde wäre verödet, und jene dunklen Gestalten, die der Himbeerpflücker noch am Leben gelassen hat, würden heute sadistisch die Knute über uns schwingen, vor meinem geistigen Auge sehe ich die triumphierenden Fratzen dieser Untermenschen, wie sie sich lustverzerrt an unserer planmäßigen Vernichtung weiden, unsere Fluren und Felder wären verwaist, aus wär's gewesen mit der Erhaltung unseres deutschen Waldes, keinen Aufschwung hätten wir mehr erlebt, bis zum Skelett abgemagert, würden wir, ein Schatten unserer selbst, entehrt und versklavt für die Feindmächte fronen, die dann in satanischer Weise ihr Ziel erreicht hätten: die endgültige Ausrottung des volksnahen Elements!

SCHNOPF: Wen meinen Sie damit?

HUETT: Uns!

YBBSGRUBER der andächtig zugehört hat: Es ist wahr, es gibt keine

53 An allusion to the leading Nazi theorist, Alfred Rosenberg (1893-1946). 
Phantasie, die sich das ausmalen kann, drum sage ich: Recht oder Unrecht, es war reine Selbstverteidigung [...] infolgedessen ist uns jeder Hilfesuchende willkommen, ausnahmslos.

(II, 219-220)

Such a view of recent history is very convenient, since nearly all the residents of Bad Brauning have a rather dark war-time record to conceal: Ziereis served in a Sonderkommando in Poland (II, 252-253); Zagl betrayed two fellow townsmen to the Gestapo, and only one returned (II, 255); Doktor Schnopf administered the Nazis' euthanasia programme in an old people's home (II, 257); Huett enjoyed the sport of hunting fleeing foreign workers in the woods (II, 257); the lawyer Suppinger benefited from the seizure of Jewish property and business (II, 258); the factory owner, Stadlmeier, and Ybbsgruber have continued associations which would be of great interest to the investigator, Ingenieur Bricha (II, 258) ${ }^{54}$; and last, but certainly not least, Steisshäuptl, used his position as Ortsgruppenleiter to acquire two chests of gold, taken from the teeth of concentration camp victims, upon which his post-war affluence and position as mayor has been built (II, 229-230).

With the arrival of Kerz, who is mistaken for the notorious "Himbeerpflücker" of the title, the hypocritical nature of the fascist notions of "Ehre" and "Treue", to which they all still pay lip-service, is exposed. The respectable citizens quickly hurry to ingratiate themselves with their would-be hero to further their personal interests: Suppinger obviously hopes that the Raspberry Picker will face prosecution, since defending such a notable could make his career (II, 238239); Huett and Schnopf, in their panic to cover their own dubious pasts, do their best to win over the fugitive and darken the other's name (II, 240-241, 248); and Ybbsgruber and Stadlmeier see the opportunity to betray Steisshäuptl and get their hands on his war-time loot (II, 242-243), and to this end are able to tempt the hapless Zagl to switch allegiances, with the promise of financial reward which would allow him to marry the far more sensible Burgerl (II, 243-244). Matters are further inflamed by the behaviour of Kerz, who, while not fully comprehending what is going on, is quite prepared to play along and exploit the situation for his own gain.

At the centre of all this activity and intrigue stands Steisshäuptl, who shows himself prepared for and capable of anything to protect his own position. $\mathrm{He}$, more than any other character, is representative of the unrepentant, self-serving old Nazi, whom Hochwälder wishes to expose and attack. The hypocrisy of his position is humorously highlighted by his relationship to his daughter, whose decision to dye her hair red at first incenses him: "[...] was glaubt das Weibsbild eigentlich, von wem ist sie die Tochter, von einem Greißler, einem Proleten? - Weiß sie nicht, was sie dem Vater schuldig ist in der Moral? [...]" (II, 227). Yet, once he believes that the Himbeerpflücker has returned, he no longer concerns himself with her moral well-being but actively encourages his daughter's interest in his unwanted guest as a means of finding out what he wants (II, 231-232).

54 An allusion to Wiesenthal. 
Indeed, Steisshäuptl has mixed feelings about the return of the Himbeerpflücker. His first reaction is one of annoyance at the threat this may pose to local business, and his main concern is to get rid of his unwelcome guest as soon as possible:

Der Himbeerpflücker in Brauning - Daß mir das passieren muß, wo wir nächstes Jahr einen Zustrom erwarten, Kurgäste aus'm Altreich, Engländer, vielleicht sogar Amerikaner... Der geringste Skandal, und es ist aus mit'm Aufschwung [...] Ich bin der Bürgermeister, es geht ums Gemeinwohl, jedes leere Zimmer ist ein Schaden für mich in der Saison [...] Was bildet er sich ein, bin ich vielleicht sein Verschworener? [...] so eine selige Ruhe war hier, ein Gottesfrieden, man hat nur ans Verdienen gedacht $[\ldots]$

(II, 228-229)

However, when Zagl points out how vulnerable he is because of the stolen gold, his tune quickly changes and suddenly the Himbeerpflücker deserves sympathy and help, a man who has been punished enough: "[...] einmal muß ein Schlußstrich gezogen werden", (II, 230). An alibi about the gold is immediately created, in a manner that leaves Zagl impressed: "Mit dem wird keiner fertig. - Eine Führernatur" (II, 231).

But, while this behaviour is prompted by the need for self-preservation, there is another side to Steisshäuptl, and indeed to the other members of his community, which still longs for the days of old, and which allows him to tell Kerz: "Ich bin genau wie Sie der geblieben, der ich war, wenn Sie mich auseinanderschneiden, möchten Sie es sehen" (II, 233). After this meeting his emotions take over, and he carries Zagl with him:

STEISSHÄUPTL: [...] Was war man damals, und was ist man jetzt? Reich, aber, vom Idealen her betrachtet, ein Dreck! (In steigender Begeisterung:) Ortsgruppenleiter! - Wenn ich dran denk, kommt mir die Gegenwart wie ein böser Traum vor, damals hat das Erwartungsfrohe geherrscht, das Aufopferungsvolle - damals haben wir den Alltag vergessen, nein: er hat uns vergessen, er war keiner, die Fanfaren, der Fahnenschmuck, die Standarten, die Straßen haben gedröhnt unter unserm Schritt, schwarzes Lederzeug, der Atem der Geschichte - und plötzlich ist alles wieder da, mit einem Schlag bin ich wieder der alte, junge Kämpfer, und warum? (Ohne Zagl zu Wort $z u$ kommen zu lassen:) - Weil wieder "Blut und Ehre" um mich ist, er hat's mitgebracht - jawohl, ich bin stolz darauf, daß ein Held bei mir eingekehrt ist, ich mach aus meinem Herzen keine Mördergrube: ich möcht weitermarschieren, und wenn alles in Scherben fällt! [...]

ZAGL bleibt stehn; verträumt: ... und morgen die ganze Welt... (Blickt auf; leise:) Wenn man ihm zuhört, glaubt man, es ist wieder damals...

(II, 234-235) $)^{55}$

55 Hochwälder himself drew particular attention to this passage in his essay, "Über mein Theater" [Im Wechsel der Zeit, 100-101]. 
But this return to the days of old is merely illusionary, and the failure of his colleagues to live up to Steisshäuptl's supposed ideals leads to the drunken outburst and denunciations:

Ein Held hat mich aufgesucht, heimgesucht, ein von allen Hunden Gehetzter - Ernst Meiche, der berühmte Himbeerpflücker vom Lager Wüstenhofen - eine Ungerechtigkeit, daß man ihn noch deswegen verfolgt, es war eine andere $\mathrm{Zeit}^{56}$, und wo gehobelt wird, fliegen Späne [...] wohin soll er sich wenden, bekanntlich hat sich in unserer Brust nichts geändert, wir können wählen, wen wir wollen, innerlich sind wir geblieben, was wir waren, infolgedessen möcht man annehmen, daß die Kameraden in so einer Situation wie ein Mann zusammenstehn, aber nein [...] man veschwört sich gegen mich und will mir meinen Ehrengast abspenstig machen, rauben, heimtückisch entfremden [...]

This speech concludes with the most telling remark of all about the Nazi past:

[...] das Entscheidende ist die Treue... Wenn der Hitler den Krieg nicht verlor'n hätt, wär er noch heut' mein Führer ${ }^{57} \ldots$ Es war sein einziger Fehler, ich kann's ihm nicht verzeih'n, er hat den größeren Weitblick gehabt. (Brüllt:) Sieg Heil!

(II, 259)

The outburst of this unrepentant Nazi has the others fearing a full investigation that will result uncover their own sordid pasts, and in desperation they must turn to the man they had hoped to usurp (II, 264). The final act has Steisshäuptl firmly in control, and even if Kerz had not been uncovered as an imposter, it is clear that matters would satisfactorily have been swept under the carpet.

The final irony is that the man mistaken for a mass murderer cannot abide violence, a fact that led to the robbery being botched and two of the burglars caught, when Kerz refused to deal with the night-watchman: "[...] ich kann kein Blut sehn, mir wird einfach schlecht... Ich tu alles, aber Mord - (Leise:) Nein!" (II, 225). He has no aspirations to be a hero in Grappina's sense of the word: "Held? - Wie kommst du drauf? - War keiner, werd nie einer sein, ich bin international: achtzehn Vorstrafen in fünf Ländern, aber ich kann nicht mit einem Stück Eisen auf einen Menschen los [...]" (II, 226). When he finally discovers for whom he has been mistaken, he is horrified (II, 268). His refusal to continue to play the part of the monster leads to his break with Grappina (II, 270), who shows a completely callous and anti-Semitic attitude to the news:

[...] die Trauermiene kauft dir niemand $a b$, fehlt nur, daß du in Tränen

56 This defence for past crimes is not dissimilar from that used later by the much more sympathetic character, Dwomik, in the later play, Der Befehl.

57 In an interview Hochwälder described this sentence as the "Kernsatz" of the play [René Freund, "Es geht sowieso schlecht aus", Wiener Zeitung, 23. Mai 1986, 4]. 
ausbrichst... Was gehn dich die Toten an, sind es deine Brüder, deine Verwandten? - da wächst Gras drüber, meterhoch, die meisten waren ohnehin bloß Juden [...] les sales juifs qui font le commerce -

(II, 270)

In this twisted post-war Austrian world, moral values are inverted and in Grappina's words: "morden ist nobler als stehlen" (II, 270). The reaction of the others when they learn the truth is that of horror at his crime, and Ybbsgruber observes with disgust Kerz's insistence that he is no mass murderer: "Er ist noch stolz darauf' (II, 274).

Not only in the eyes of the men is mass murder far more heroic than the crime of theft, such violence clearly has a strong sexual appeal to the women. Grappina bemoans Kerz's lack of killer instinct in comparison with previous lovers (II, 226), while for Sieglinde, who initially refused to believe the mundane truth, the news takes the edge off their liaison: “... der Mann... das Auftreten... die Erscheinung... nein: es war schön, trotzdem. Freilich, schöner wär's gewesen... (Seufzend:) Schad', ewig schad'!" (II, 274).

Yet the one positive figure among the population of Bad Brauning is, typical of Hochwälder, a woman, the cook, Burgerl. She is the only character to see things as they really are, often throwing cold water on the romanticised imaginings of the others, particularly those of the hapless Zagl. In the opening scene, for example, when Sieglinde's new hair-style has caused consternation, she quickly destroys Zagl's illusions about their master, Steisshäuptl:

ZAGL: Wenn es um die Moral geht, ist er eisern, als Witwer und Bürgermeister, und zuletzt muß ich es ausbaden, das ist mir schon zu blöd.

BURGERL: Er ist imstand und haut alles zusammen, als ehemaliger Bierfahrer -

ZAGL: Wirf ihm nicht den Bierfahrer vor, er ist eine Respektsperson [...]

Burgerl alone does not get caught up in the panic that erupts with the arrival of Kerz and finds the behaviour of the others quite ridiculous, putting it down to the weather (II, 241). Nor is she taken in by Zagl's new-found confidence which prompts him to propose to her, but rather she is horrified by the fact that he is prepared to betray his master: "... heiraten... das Krepierl... und zum Stadlmeier... (Stemmt die Hände in die Seiten.) So ein Haderlump, so ein Verräter - und so was redet noch vom Mark der Ehre!" (II, 249). Her main concern remains peace and quiet (II, 254, 263).

Most importantly at the end, it is only Burgerl who has any sympathy for Kerz. She sharply attacks the behaviour of the others:

Ja, was bildt's ihr euch denn ein? - Ich red nichts, aber einmal reißt mir die Geduld, wollt's ihr keinen Frieden, keine Ruh? - Seid's ihr nur selig, wenn ihr auf einen andern losgehn könnt's, wer ist denn was bei euch? Wenn einer ein paar tausend Menschen umbringt, was, dann schlieft's ihm in den Hintern, aber auf einen armen Hund trampelt's ihr herum, pfui 
Unfortunately, this question has already been answered by Zagl: "Nein, ich bin kerngesund" (II, 261), and while Steisshäuptl can ask at the end; "bin ja kein Unmensch, nicht wahr...?" (II, 276) the behaviour of the majority and their lack of repentance at the end would prompt a negative answer. Burgerl as the sole positive figure is outnumbered, and the play does not end with her plea for kindness but with Steisshäuptl's triumph.

Of course, the fact that they have all been made fools of is now the cause of some embarrassment, and recriminations, but soon the familiar racial stereotype comes to the rescue:

HUETT: Bedenken Sie: wer war noch immer an allem schuld? (Näher:) Die Visage ist mir sofort verdächtig vorgekommen: Krummnase, Schädelform, Haaransatz - alles weist eindeutig auf einen Angehörigen der semitischen Fremdrasse hin, die unserm Volk allezeit zum Verderben gereichte -

YBBSGRUBER: Was - ein Jud?

HUETT: Als gewiegter Rassenforscher schließe ich jeden Zweifel aus.

STADLMEIER: Ein Jud also...

STEISSHÄUPTL zerknirscht: Ein ganz gewöhnlicher Jud...

All that is now required to leave Steisshäuptl fully victorious is the news that the real Himbeerpfliuckeris dead. Unrepentant to the end he can triumphantly propose a toast in memory of their dead hero (II, 276). Life in Bad Brauning can now return to normal.

This conclusion has prompted Best to suggest:

[...] Der Himbeerpflïcker is so closely rooted in reality its characters are not, in the final resort, obliged to change. Steißhäuptl may panic, but he shows none of the remorse or fundamental shift in attitude that overtook the money-lender Berullis. Berullis after all was safely set in the context of a 'dramatic legend' where such moral shifts may be possible. The reality is markedly grimmer ${ }^{58}$.

Yet this is, of course, Hochwälder's point: post-war Austria has not been forced to confront its sordid past in the way Berullis was. That is not to imply that such a confrontation will not lead to change, and in the second of the two published plays concerning Austria's brown heritage, Der Befehl, such a forced confrontation does indeed occur, with quite different results.

Any examination of this play is complicated by the existence of two versions: that written for television and broadcast in January $1967^{59}$; and the exten-

${ }^{58}$ Best, 56-57.

${ }^{59}$ Fritz Hochwälder, Der Befehl (Graz: Stiasny, 1967). Hereafter this text will be referred to as follows: (Der Befehl, page no.). 
sively revised stage version, first performed in March 1968 at Vienna's Burgtheater and published in the collected plays.

Both versions have in common with their predecessor the theme of Vergangenheitsbewältigung and are populated with characters who have adapted to post-war society without ever really having to confront or renounce their Nazi pasts. In the earlier version the minor characters, Tod (Der Befehl, 25) and Takatsch (Der Befehl, 29), can look back fondly to when they were in the position to instill fear in others; the character Pokorny, in both versions, has had to distance himself from his war-time past, but always has time for 'old comrades (Der Befehl, 21; II, 310); and Hainzl in the stage play is delighted to see his partner again and reminisce about the Amsterdam days: "[...] das Herz hängt an der Zeit, sowas vergißt man nicht [...]" (II, 316).

The behaviour of the authorities also shows a considerable degree of reluctance to bring to justice those with dubious war-time pasts. They pursue this particular crime from the days of the Third Reich for reasons of political expediency and the desire to help delicate diplomatic negotiations (Der Befehl, 10; II, 282). But such efforts are the exception rather than the rule, as is made evident by the fact that Poslanetz is able to find such a ready suspect in Muff, a man "schwer belastet", about whom it is recorded that he was "Besonders brutal beim Abtransport von Kindern", and yet who has, apart from a five-month prison sentence at the end of the war, been allowed to carry on a quiet existence as a free man (Der Befehl, 40; II, 304). In the earlier play Muff flees before he is arrested, even though he is innocent of this particular murder, because: "Der Schuft hat verschiedenes auf den Kerbholz" (Der Befehl, 73). But despite this, once he is cleared of the murder of de Goede's daughter, the police show no interest in other crimes he might have committed (Der Befehl, 74). This lack of concern is made even clearer in the stage version, for here Mittermayer lets Muff go free, despite the fact that the shrewd Dwornik is convinced he has something else to hide (II, 329). Indeed, he has admitted other crimes when drunk (II, 324-325). As with Mittermayer, alcohol reveals much about the character's true nature.

While the generation active during the war years shows itself unperturbed by the past, the younger generation, here represented by Poslanetz, just as it had earlier been represented by Sieglinde, shows itself to be made of no better moral fibre. Mittermayer's young, ambitious colleague, ruthlessly pursues his own advancement, and even when Muff is cleared of the crime he is prepared to frame such a perfect suspect (Der Befehl, 74; II, 329). Even the sentiments he expresses about his colleague Dwornik have more than a faint echo of the rhetoric of the Nazis in Himbeerpflücker: "Er denkt nur an sich, das Ideal ist nichts" (Der Befehl, 72; II, 325).

In addition to this, in the television version of the play, a young couple see Mittermayer drowning but do nothing to save him (Der Befehl, 82), an ironic end to the protagonist, considering his earlier crime, and one that suggests that humanity has not improved. 
As with the two previous plays that dealt with the Nazi past, Der Befehl was also inspired by an actual event: in this case the arrest of Karl Silberbauer, in 1963, who admitted arresting Anne Frank during the war ${ }^{60}$. Like Silberbauer, Mittermayer is an officer in the Viennese Police and his war crime also took place in the Prinsengracht of Amsterdam. Nevertheless, while the basis for the story can be found in fact, this merely provides Hochwälder with the impetus to explore further not just the Nazi past but favourite themes such as the nature of evil, the extent to which one individual can truly know another, and most importantly, the individual's relationship to authority. Surprisingly, considering that the earlier play, Der Himbeerpflücker, is a far more savage attack on latent fascism within modern society, Der Befehl caused far more controversy, not so much in Austria, but in West Germany, when at the last minute it was withheld from broadcast by German television. This decision was all the more astonishing for two reasons: it had already been broadcast in Austria, Italy, Switzerland, and Britain, where it had been praised as "a merciless study of guilt" 61 ; and it was a co-production involving the German second channel, ZDF. Less surprising was the outcry the decision caused. Certainly, suggestions by television management that the play was "nicht kritisch genug" and "zu verharmlosend" failed to convince journalists ${ }^{62}$ and clearly is not borne out by the text, which had been published prior to the date of broadcast and was already available in Germany. Fears that it might encourage the far right were far from confirmed by the right-wing press, where the play was seen as a further example of the "Diffamierung der österreichischen Bevölkerung"63. Nevertheless, such criticisms were also voiced in Holland, where the play was not broadcast, as it apparently did not correspond with Dutch perceptions of the Nazi occupation of the Netherlands ${ }^{64}$. Hochwälder himself was far from happy with the German television pro-

\section{0} Hochwälder conceded this to the German weekly, Der Spiegel [Anonym, "Feldmaus Ödipus", Der Spiegel [Hamburg], Nr. 4, 16. Jan. 1967, 83], and newspaper cuttings concerning the Silberbauer affair can be found in the Nachlaß. The case was a further example of the willingness of Austrian authorities to conceal the past, which had so troubled Hochwälder in correspondence, as is revealed by Wiesenthal's account of the uncovering of Silberbauer: the authorities had wished to keep the matter secret but Silberbauer, incensed at his suspension complained to the wrong person and the story was leaked to the media [Wiesenthal, Justice not Vengeance, 399-400]. Further information on Silberbauer's role in the murders of the Frank family is provided in: David Barnouw, and Gerrold van der Stroom, ed., The Diary of Anne Frank. The Critical Edition. Prepared by the Netherlands State Institute for War Documentation, Trans. Arnold J. Pomerans and B.M. Mooyaart-Doubleday, (London: Viking, 1989).

61 Anonymous, "A merciless study of guilt", The Times [London], 19 Jan. 1967.

62

Bernhard Schütze, "Händeringen in Mainz", Abendzeitung [München], 26. Jan. 1967. Cf. Hilde Spiel, "Befehlsverweigerung", Frankfurter Allgemeine Zeitung, 24. Jan. 1967, 18; Wolfgang Kraus, "... in der Nazizeit", Der Tagespiegel [Berlin], 25. Jan. 1967; Rudolf Krämer-Badoni, "Das abgesetzte Fernsehspiel", Die Welt [Hamburg], 26. Jan. 1967; Br., "Verharmlosung?", Frankfurter Allgemeine Zeitung, 27. Jan. 1967, 18; W.M. Guggenheimer, "Die wahre Befehlslage", Süddeutsche Zeitung [München], 27. Jan. 1967; Otto Köhler, "Lebenshilfe", Der Spiegel [Hamburg], 30. Jan. 1967, 99.

63 Anonym, "Österreich, Deine NS-Verbrecher! Fernsehlügen über Wiens dunkelstes Kapitel", Deutsche Nationalzeitung, 3. Feb. 1967.

64 Anonym, "Feldmaus Ödipus", Der Spiegel [Hamburg], Nr. 4, 16. Jan. 1967, 83. 
duction, which he described as: "[...] eine Katastrophen-Inszenierung meines Befehl exekutiert vom Edwin Zbonek, der eine Mischung von Marcel Carné und Franz Antel ist (dieser ein bekannter Hersteller von Heurigen-G'schnasfilmen $[\ldots]^{\prime 65}$, but as he himself recognized, the controversy surrounding it did the play no harm at $a 11^{66}$.

Yet, even after the substantial reworking for the stage production, Hochwälder still found himself attacked and misunderstood from both sides: "Praktisch gesprochen, habe ich mich mit dem Stück zwischen zwei Sesseln gesetzt [...] indem nämlich mir einerseits Versöhnlertum (von dem ich im Stück nichts entdecken kann) vorgeworfen wird, andrerseits die Nazis mich begeifern, was mir bedeutend willkommener ist $[\ldots]^{, 67}$. The stage version was also to have its share of controversy with an outburst from a member of the audience claiming: "Dieses Stück ist eine Verleumdung des österreichischen Volkes" 68 , and, as Hochwälder revealed in correspondence, the leading actor was sent threatening letters after appearing on stage to support the play ${ }^{69}$.

Certainly, such outbursts and the withdrawal of the play from German television suggest it had hit a rather raw nerve, angering the neo-Nazis while failing to deliver the easily digestible and quickly forgettable National Socialist stereotypes for non-sympathisers to swallow; as W. M. Guggenheimer suggested after the ZDF decision: "Die österreichische Ironie und Nonchalance [...] passen freilich schlecht zu dem zähen Bestreben der Deutschen, die Banalität des immer lauernden Bösen wenigstens durch düstere Nibelungendämonie aufzuplustern" $" 70$.

Hochwälder made substantial changes to the play before it was performed on the Viennese stage; indeed the two versions are so different that he was to write of the Burgtheater production: "Es handelt sich tatsächlich um eine Uraufführung, denn das Stück hat mit dem gleichnamigen Fernsehspiel nicht viel mehr gemein [... $]^{, 71}$. The dramatist also drew Holdman's attention to this and suggested a comparison between the two would be worthwhile ${ }^{72}$.

65 Fritz Hochwälder, Brief an Ernst Waldinger, 5. Feb. 1967, Dokumentationsstelle für neuere österreichische Literatur, Wien. The original director was Erich Neuberg, but Zbonek replaced him after he committed suicide, cf. F. H., Brief an E.W., 14. Feb. 1967.

suppressed", Fritz Hochwälder, "My Theater", undated, Hochwälder Nachlaß, Wiener Stadtund Landesbibliothek, Wien.

67 Fritz Hochwälder, Brief an Ernst Waldinger, 15. März 1968, Dokumentationsstelle für neuere österreichische Literatur, Wien.

68 Anonym, "Zwischenfall beim Befehl", Volksblatt [Wien], 8. März 1968.

69 Fritz Hochwälder, Brief an Ernst Waldinger, 15. März 1968, Dokumentationsstelle für neuere österreichische Literatur, Wien.

${ }^{70}$ W. M. Guggenheimer, "Die wahre Befehlslage", Süddeutsche Zeitung [München], 27. Jan. 1967.

71 Fritz Hochwälder, Brief an Ernst Waldinger, 22. Jan. 1968, Dokumentationsstelle für neuere österreichische Literatur, Wien.

72 Holdman, 120. 
Many of the changes are clearly caused by the requirements of different media: changes in location between Vienna and Amsterdam have been removed and the rapidity of scene changes has been lessened, in keeping both with the confines of the stage and Hochwälder's fundamentally conservative approach to staging. Furthermore, the Jekyll and Hyde schemata between Mittermayer and his former self is gone:

Die Dramaturgie ist, bei häufiger Beibehaltung entscheidender Dialogartieen, eine durchwegs andere: alles was im filmischen Fernsehen durch Vision und innere Stimme dargestellt werden konnte, funktioniert nunmehr bühnenmässig. Zu diesem Zweck habe ich Mittermayer in zweiter Fassung verheiratet, so dass er sich "aussprechen" kann ${ }^{73}$.

However, another change which has less to do with staging requirements is the visit by Mittermayer to the psychologist to find out if it were possible to "forget" an unsavoury incident in one's past (II, 300-302). Hans Heinz Hahnl ${ }^{74}$ has suggested that this was a response to the wide criticism of the television version in which many found it unlikely that Mittermayer could forget his earlier crime ${ }^{75}$. This psychological justification is reinforced in the later version by Mittermayer's abstinence from alcohol: in the television version Mittermayer has never drunk, as Pokorny testifies (Der Befehl, 20), and it is revealed that his father died an alcoholic (Der Befehl, 37); whereas in the stage play alcoholism in part explains Mittermayer's loss of memory, for he got blind drunk after the murder (II, 311-312) ${ }^{76}$.

Holdman has argued, rather unconvincingly, that the television version is "more dramatically conceived than the theater version"77, and suggests that:

[...] the more compact structure of the stage play seems to diminish the figure of the protagonist, Mittermayer, and render him less sympathetic. At the same time, the longer scenes permit a more expansive style of dialogue that diffuses the dramatic impact created on television by the concentrated speech and "pregnant silences" $[\ldots]^{78}$.

\footnotetext{
73 Fritz Hochwälder, Brief an Ernst Waldinger, 25. Aug. 1967, Dokumentationsstelle für neuere österreichische Literatur, Wien.

74 Hans Heinz Hahnl, "Mit szenischer Beredsamkeit argumentiert", Arbeiter-Zeitung [Wien], 5. März 1968.

75 G. Obzyna, "Das Abgründige in Herrn Mittermayer", Express (Morgenausgabe) [Wien], 20. Jan. 1967; Horst Dieter Sihler, "Fritz Hochwälders Der Befehl", Kärntner Tageszeitung [Klagenfurt], 21. Jan. 1967; bf., "Sie schämten sich des Befehls", Münchner Merkur, 24. Jan. 1967; Hilde Spiel, "Befehlsverweigerung", Frankfurter Allgemeine Zeitung, 24. Jan. 1967, 18.

76 In both plays alcohol also serves as the lubricant to expose Mittermayer's true nature, prompting the appearance of Mittermayer's darker side, the "Grïnen" in the television version (Der Befehl, 32-34; 67-68; 82), while leading to his brutal behaviour toward his wife in the stage version (II, 320-321).

77 Holdman, 131.
78 Holdman, 124.
} 
In part, Holdman's argument is based on the fact that at the time she was writing only the television version was in print, supposedly reflecting "the vitality of the original"79. However, this state of affairs changed with the publication of the collected dramas, and it is significant that it is the stage version which is published in Dramen $I I$, and not the Eurovision script.

Indeed, in many respects the later version is a major advance on its predecessor, not only allowing greater development of the personality of the protagonist, but also expanding the role of Dwornik, which in turn allows a more succinct presentation of the ideas at the heart of the play. Despite Holdman's assertion, a more rounded, sympathetic Mittermayer is apparent from the first scene of the stage play. Here, the protagonist is seen in his domestic environment, at home with his wife, and the expositional detail about his nervous breakdown as well as his own insecurity and fears is revealed first-hand (II, 279-281) ${ }^{80}$. Mittermayer's behaviour is also more convincing in the later play when he meets de Goede for the first time and learns what his task will be. While he is shaken in both versions by what he hears, dropping his pencil, in the former he regains his composure more readily, remains decidedly cold toward the Dutchman and refuses to shake his hand (Der Befehl, 11-16) ${ }^{81}$. In the latter version he remains shaken, earning a reprimand from his superior for his behaviour, and he attempts to get out of the assignment (II, 286-290). This behaviour is also elaborated on to Anna in a later scene, which makes it quite clear that Mittermayer already half suspects himself (II, 297-299). This scene and the visit to the therapist (II, 300-302) strengthen the portrayal of a man truly horrified by what he is uncovering.

Furthermore, by removing the television gimmickry of the apparition of his former self, attention rests firmly on the contemporary Mittermayer, and his struggle to come to terms with his own past and personal guilt: only in one brief scene is it shown just how vicious he can be (II, 320-321). This has the double impact of heightening the shock of this sudden brutality, since it is such an isolated incident, and, because it is Mittermayer who is responsible, rather than the apparition of his former self, makes it quite clear that the present-day Mittermayer, is still capable of violence. This takes on great importance in light of the additional dialogue between the protagonist and Dwornik in the last act of the later play.

The most important change between the versions is the expanded role of the character Dwornik. While in both versions, he uncovers the truth about Mittermayer, in the latter play he has considerably more influence on events, suggesting that Mittermayer start his inquiries with his former commander in Amsterdam (II, 306) and then checking to see whether Mittermayer has actually visited him (II, 314). On his own initiative, he sends for and examines

79 Holdman, 120.

80 This is conveyed through the telephone conversation of the Oberpolizeirat in the earlier version (Der Befehl, 7-8)

81 This is not the first time that Hochwälder has used this gesture to convey hostility: Cf. Der Fliichtling, and Chapter 2. 
Mittermayer's file (II, 307), whereas in the earlier script, Mittermayer himself suggests that they should start with his file (Der Befehl, 18) ${ }^{82}$.

But the most important change regarding Dwornik in the Bühnenfassung is in the last act, where he propounds a point of view counter to Mittermayer's and where he, and not his superior, visits de Goede at the end, after trying to persuade Mittermayer to do so:

DWORNIK: [...] melden Sie sich bei diesem Herrn de Goede. - Er will keine Anzeige, keinen Prozeß; er will dem Täter lediglich gegenüberstehn, ein einziges Mal. - Der Mann ist krank wie Sie - er wird mit der Vergangenheit nicht fertig. - Helfen Sie sich und ihm und sagen Sie die Wahrheit: "Ich war's, aber ich bin es nicht".

Pause.

MITTERMAYER: Nein, Dwornik - (Richtet sich auf.) Ich war es, und ich bin es.

DWORNIK: Es war die Zeit -

MITTERMAYER: Es waren die Menschen.

Mittermayer's conviction that he has not really changed leads to his suicide, reported in the last act (II, 331-332), but it is with Dwornik that the play closes, when he presents himself to de Goede as the potential murderer of his daughter:

Herr de Goede - schauen Sie mich an. [...] So und nicht anders sieht der aus, der die Untat auf dem Gewissen hat. [...] Eine Bestie damals, unleugbar. - Und heute, im zivilen Alltag, ein gewöhnlicher Durchschnittsmensch, dem niemand etwas Böses zutraut. [...] Sie stehen dem gegenüber, den Sie suchen, und wenn Ihnen dran nicht genug ist, tun Sie einen Blick aus dem Fenster: jeder Fünfte, Sechste, der vorübergeht, könnt es genauso sein. - Wohlgemerkt: in einer anderen Zeit und unter andern Umständen. [...] $\mathrm{Daß}$ ich es faktisch nicht gewesen bin, ist nicht mein Verdienst. Die Zeit damals, die Menschen... Die Uniform, der Karabiner, der Einsatz, der Befehl, die Aufregung, die Angst, die blinde Wut... und nicht zuletzt die abgrundtiefe Feigheit, die zum Exzeß gegen Wehrlose führt... Wer weiß wieviel Selbsthaß in der menschlichen Bestialität steckt? Wer kennt sich denn genau? - Wer kann jederzeit die Hand für sich in Feuer legen? - Ich nicht.

[...] Der grüne Polizist, der Ihr Kind erschlagen hat, ist tot. - Er hat gebüßt, und ich habe geahnt, daß er es tun wird. - Damit ist nichts aus der Welt geschafft, und nichts - aber auch nichts - entschuldigt. - Ich bin nicht besonders religiös, aber ich glaube: manchmal bleibt einem nichts übrig, als sich zu bekreuzigen - nicht vor den andern, nein: vor sich selbst. - Und es sollten sich viele auf diese Weise bekreuzigen.

(II, 334-336)

82 In this version Dwornik does examine Mittermayer's file, although stage instructions give the impression that this is a spur of the moment act: "Will die Mappe ablegen - besinnt sich, greift zur Pfeife, zündet sie an; schlägt auf und vertieft sich in das Dossier über Mittermayer". 
The placement of this speech gives it considerable weight, and Holdman has seen this figure, in both versions, as "a mouthpiece for the author" 83 . James Schmitt is more circumspect, claiming that the play does not make clear whether Hochwälder supports Mittermayer's or Dwornik's view of the past ${ }^{84}$, a point of view strengthened by Hochwälder's response to queries by Schmitt:

Es scheint mir Mittermayers Aussage: 'Es waren die Menschen' wesentlich; und das sich jeder bekreuzigen möge, soll etwas heissen vor der jederzeitigen Möglichkeit des eigenen Bösen ein Kreuz zu schlagen. Als Schluss des Stückes ist diese Aussage sehr wichtig ${ }^{85}$.

Daviau seems to accept uncritically Dwornik's closing words, in comments that, had they been written at the time of the television production, might well have been used to strengthen the justification for preventing broadcast in Germany:

This work [...] shows a radical shift in Hochwälder's attitude toward war criminals: whereas in earlier plays he had always insisted that they should be punished, here his attitude is one of tolerance and reconciliation, rationalizing their behavior simply as a manifestation of the times. Just as in Der Unschuldige he indicated that everyone could uncover a skeleton from the past, he now argues that anyone who was not forced into guilt by the fascist system should count himself lucky. This debatable thesis makes the play controversial, for Hochwälder's suddenly altered view of former Nazis as decent people who were forced into guilt by the circumstances of the time is not widely shared ${ }^{86}$.

That Hochwälder would not share such a simplified view of the play is apparent from the comments quoted above, and it is not surprising that Daviau quickly gets himself into trouble in the same article, indeed on the very next page, when he attempts to portray Mittermayer as a man with the integrity to accept responsibility for his former actions, while seeing Dwornik, the character whose views he sees as carrying the message of the play, as a man with a "malleable" conscience able "to blame everything on circumstances and assume none of the blame himself" 87 .

To remove such confusion it is necessary to examine the basic plot at the heart

83 Holdman, 132.

84 Schmitt, "The Theme of Responsibility...", 117.

85 Letter from Fritz Hochwälder to Schmitt, April 12, 1972, quoted in Schmitt, "The Theme of Responsibility [...]", 118.

86 Daviau, "Fritz Hochwälder", 258.

87 Daviau, "Fritz Hochwälder", 259. Daviau's dislike of Dwornik is made even clearer in a later article when he sees him as an unrepentant Nazi and a "Nichtmenschen" (Daviau, "Der innere Konflikt [...]", 922); harsh words indeed for the character who, it would seem, espouses the views that Daviau sees as the central message of the play. 
of both versions: a conscientious officer is required, Oedipus-like, to investigate a crime of which he himself is guilty. This theme of revisiting the past differs from the earlier play, Der Himbeerpfliicker, in that, although the plays are littered with former, unrepentant Nazis, the protagonist himself is not one, not even, as Daviau claims, a "decent" Nazi. This is made quite clear early on in both versions when it is revealed that Mittermayer served, prior to 1938, in the department responsible for combating illegal National Socialist activity, a fact which severely damaged his career until the war led to a shortage of personnel (Der Befehl, 7; II, 283). This is not the tale of unrepentant fascism but an exploration of how a fundamentally decent but weak individual can be drawn into a web of evil. In this respect, Der Befehl has more in common with Holokaust than Hochwälder's anti-fascist satire, and in Mittermayer's dedication to duty continues a theme seen in earlier plays such as Das heilige Experiment, and Der Flüchtling. It is this subservience to orders which is at the heart of the play, and which makes it, in Hochwälder's own words "die Tragödie des kleinen Befehlsempfängers" 88 .

Just how far Mittermayer will go in carrying out his duty is made clear in the opening scene of the stage play, when he reveals to Anna that he has reported his earlier nervous breakdown himself:

MITTERMAYER: Es steht in meinem Personalakt.

ANNA: Ausgeschlossen. - Der Chefarzt hat es nicht gemeldet.

MITTERMAYER: Es gehört hinein. Ich war immer korrekt.

ANNA: erbittert: Du wirst noch einmal dran zugrunde gehn. [...] für dich existiert nichts als Befehl, Gehorsam, Dienst. [...] Korrekt, immer korrekt... als ob die Menschheit nicht längst genug davon hätt.

There is no equivalent of this in the earlier version, but in the early scene with the Oberpolizeirat in both plays, it is clear that Mittermayer wishes, prophetically, to die in the force (Der Befehl, 8-9; II, 284-285), and in both he involuntarily straightens when given the fateful directive (Der Befehl, 9; II, 290), much to the amusement of his superior in the television production: "Wie ein Zirkuspferd beim Trompetenklang" (Der Befehl, 9).

Yet for all his dedication to duty and insistence on correct procedure, even when it may be to his personal detriment, the crime he is ordered to investigate, the one of which he himself is guilty, resulted from an occasion when he did not follow an order. This point has been neglected by the critics, yet it adds a further nuance to the title. Pokorny makes it quite clear that Mittermayer was to bring de Goede and his daughter back alive, and that the failure to do so caused him difficulties:

Ich habe Order gehabt, den Kerl samt Brut dingfest zu machen, drum hab ich Sie eingesetzt, meinen verläßlichsten Mann, und einen zweiten zur

${ }^{88}$ Fritz Hochwälder, Im Wechsel der Zeit, 101. 
Beihilfe - und was passiert? -: einer wie der andere kehrt mit leeren Händen zurück, eine Katastrophe. - Mir war befohlen, das Mädel lebend abzuliefern, aus einer Minderjährigen kriegt man alles heraus und dann hätte man die ganze Bande hoppgenommen, aber mit einer Toten

$$
(\mathrm{II}, 311)^{89}
$$

The irony of the fact that the disobeyed order causes so much grief for the protagonist is further heightened by the order he received from Pokorny immediately after the murder: to forget it ever happened. That Mittermayer has carried out this order to the letter certainly impresses Pokorny in both versions of the play: on television he exclaims: "Daß Sie ein ausgezeichneter Befehlsempfänger waren, hab ich zwar immer gewußt, aber daß es derart tadellos funktioniert, durch die Jahrzehnte..." (Der Befehl, 22); while in the stage version he draws a wider message from this "exemplary" behaviour:

Da sieht man wieder, was ein Befehl ist. - Krasser Fall, aber war's der einzige? - Ist es nicht Tausenden ähnlich ergangen? - Gedächtnisschwund einer Generation, ebenso nützlich wie notwendig. - Wo kämen wir hin, wenn uns die Vergangenheit auf Schritt und Tritt verfolgt? - Was wir getan haben, hat nichts mehr mit uns zu tun, ich lehne es ab, dafür grad zu stehn - wir waren andere damals, und die andern auch. - Wenn heute ein Kind ins Wasser fällt, spring ich ihm nach und rett es unter Lebensgefahr; damals war's mir egal.

$(\text { II, } 312)^{90}$

Pokorny's convenient philosophy, which has more than a little in common with Dwornik's view that the times were to blame, also gets support from the analyst Mittermayer visits, who sees the ability to forget past crimes as part of healthy human behaviour:

Da wimmelt es von Kreaturen, die Fürchterliches begangen haben - es stört sie nicht, sie schlafen ausgezeichnet und sind womöglich noch stolz darauf. [...] Freilich: ob geistige Gesundheit nicht mit Stumpfheit gleichzusetzen ist - die Frage steht auf einem andern Blatt.

(II, 302)

Mittermayer struggles to come to terms with his crime because he attempts to superimpose the current standards of what is "anständig" on to acceptable standards of behaviour under the Nazis. In this he is not alone, for his superior, the Oberpolizeirat, also expects to find evidence of what would be unacceptable now, but expected then, to be recorded in dossiers from the Nazi period (Der Befehl, 7-7; II, 283). Even the Dutchman de Goede is prepared to state: "Sicher hat es auch unter den 'Grünen' anständige Leute gegeben, die sich nichts zuschulden kommen ließen" (II, 289).

89 This passage, in slightly altered form, can also be found in the television text (Der Befehl, 22-23).

90 It is ironic that Pokorny's apparent readiness to risk his life to save someone drowning is not shared by the young couple in the earlier version of the play, who allow Mittermayer to die. 
It is then highly ironic that it is through the one time that he failed to complete his orders diligently that Mittermayer must rediscover just what it meant to be a "good" officer during the war. The protagonist must come to the painful realization that the brutality which led to the death of the girl was no isolated case, merely the only one to happen in contravention of orders. In the earlier version it is his alter ego that reveals this to a horrified Mittermayer:

DER GRÜNE: [...] Und wie wir die Jodenbreestraat abgeriegelt und die Stinkjuden einen nach dem andern ins Lastauto befördert haben nach Mauthausen - bist du nicht durch die Reihen wie ein Wilder und hast mit dem Gummiknüttel hingehaut, blindlings nach links und rechts?

MITTERMAYER stöhnend: Nein, nein -

DER GRÜNE: Lüg nicht. - Man hat uns strikt befohlen: schneidiges Vorgehn, schlagen, treten. - Gib zu: du hast einfach Schiß gehabt, nicht brutal genug zu sein. - Das war's.

(Der Befehl, 33-34)

This revelation comes from his former colleague, Hainzl in the stage play (II, 319). Clearly, it can be no defence to claim that one was merely following orders, and in the de Goede case Mittermayer cannot even fall back on that.

As Mittermayer turns to alcohol, the appearance of his former self in the television version and his violent outburst in front of Anna in the later play, demonstrate just what he is really capable of. Indeed in the latter it is even suggested that the murder was not even provoked by an attempted escape: "Soll nicht erzähl'n... Die Kleine hat ihn nicht in die Hand gebissen... Die Wut war's und die Angst, daß ihm der Fang entgeht - (Holt mit der geballten Rechten aus, schlägt in die Luft.) Krepier, Dreckmensch, lausiges -, es leben noch viel zuviel von euch -" (II, 321). While he tries to portray the murder in the third person, he cannot distance himself from his crime: "Der gleiche: gestern, heut und morgen" (II, 321).

After Mittermayer's attempt to salvage his life by pinning the blame on Muff fails, it becomes clear that he can no longer escape his past. In the earlier version he confesses to de Goede, only to find he is not believed (Der Befehl, 78-79). Again turning to drink, he is haunted by his former self and dies attempting to hit his enemy: "[er] fällt im Duell mit sich selbst" play he cannot admit his guilt to de Goede, as Dwornik suggests, because he knows, deep down, he is still the same man: "Es waren die Menschen" (II, 331). He chooses death, pursuing a gangster, which is outside his line of duty; an act interpreted by Dwornik as atonement for his crime (II, 335).

If the theme of subjugating oneself to authority, rather than accepting personal responsibility, has occurred in earlier works, the failure of individuals to know one another [see Chapter 5], or indeed themselves, is also another familiar aspect to Hochwälder's Befehl. If the world struggled to attribute crimes of such magnitude to the ordinary, banal figure of Eichmann, so too are the characters of this play inclined to make judgements on external appearances.

${ }^{91}$ Hochwälder, Im Wechsel der Zeit, 101. 
De Goede believes he can trust Mittermayer at their first meeting: "[...] der erste Blick in ein Gesicht trügt nie" (Der Befehl, 11; II, 286), and in the earlier version he refuses to believe Mittermayer's confession (Der Befehl, 78-79). The waitress at the milk bar expressed concern for Mittermayer's safety, in what may be a dangerous job, because: "Es gibt so wenig Menschen" (II, 292), clearly not imagining of what her customer might be capable. Likewise Vroom, even when Cornelissen recognizes Mittermayer's voice in the television play, cannot attribute anything untoward to the diligent inspector, although there is more than a little dramatic irony in his words: "Nein, Mevrouw... Dieser Mann ist wie besessen hinter dem Mörder her, er hat sich bloß in ihn hineinversetzt... Kriminalbeamte sind merkwürdige Leute, sie schrecken vor nichts zurück..." (Der Befehl, 64). Even Mittermayer's wife, who should know him better than anyone, discounts his early suspicions that he might have committed the crime: "[...] Seit fünfzehn Jahren sind wir verheiratet, ich kenn dich durch und durch; du bist nicht fähig, einer Fliege was zuleide zu tun [...] Glaub mir: wenn du nur im geringsten wärst wie die Bestie, die das Kind erschlagen hat - du hättest nicht reden müssen; ich hätt's gespürt, gerochen - vor Jahren schon" (II, 299). It is only when, under the influence of alcohol, that Mittermayer reveals his darker side that she sees the truth, and has her earlier words thrown back in her face: "Was schaust? - Kennst mich vielleicht nicht? - Hast es nicht längst gespürt, gerochen -?" (II, 320).

Only Dwornik, demonstrating the insight which allows him to uncover the truth, refuses to be taken in by external factors, telling Pokorny: "Das Äußere täuscht" (Der Befehl, 53) and observing: "Unglaublich, was in einem Menschen steckt..." (Der Befehl, 75; II, 330).

Dwornik's recognition of the potential evil in everyone highlights a recurrent concern of Hochwälder's, which will be returned to in the next chapter. He is quite prepared to concede that he himself might well have been the murderer: both to Mittermayer: "[...] mir war im ersten Augenblick, als hätte ich mich selbst verdächtigt. - Seien wir ehrlich: man muß kein Fanatiker gewesen sein und kein Sadist, um damals etwas angestellt zu haben, das man heute nicht mehr begreifen kann" (II, 330); and to de Goede when he presents himself as the potential killer, for "Wer kennt sich denn genau?" (II, 335). In his view of self-hate as a major motivating force in human behaviour he echoes the sentiments of Glaser's cynical resignation (Holokaust, 69).

But Dwornik's understanding of human nature, given so much weight by his closing speech at the end of the Bühnenfassung, raises as many questions as it solves. With the resolution of the murder case, he recognises that: "Damit ist nichts aus der Welt geschafft, und nichts - aber auch nichts - entschuldigt" (II, 336). Yet he offers little basis to support the imperative he issues: "Passen wir auf, daß so eine Zeit nie wiederkehrt" (II, 335) other than to turn to a faith in which, like Pomfrit, he has little belief: "[...] manchmal bleibt einem nichts übrig, als sich zu bekreuzigen" (II, 336). Indeed, his view that the times, rather than the individuals, were to blame is very similar to that of the unrepentant Pokorny: "wir waren andere damals, und die andern auch" (II, 312). 
Mittermayer's tragedy is that he recognises that in similar circumstances he would act the same way again.

Yet for all his claims to be just as capable of evil as Mittermayer, Dwornik shows himself capable of acting without authority, indeed on occasion of expressly contravening his orders, when he feels it is warranted; "Befehl, Gehorsam, Pflicht - [...] einmal kommt der Moment, wo man - mit Verlaub - drauf pfeift $^{92 "}$ (II, 331). This demonstrates an independence of action which offers slight hope for the future: the possibility of taking personal responsibility.

Nevertheless, the problem of how to overcome man's propensity to evil remains unanswered by the play, and it is in this sense Hochwälder's ambiguous answer to Schmitt must be understood: while individuals must be held accountable for their actions, it remains unclear how inhumanity can be held in check, unless it is through the dictates of their own consciences. Certainly, it is this belated recognition of personal responsibility that leads to Mittermayer's death [see Chapter 8]. However, nothing has changed with the death of one war criminal, as Dwornik makes clear at the end.

Whether drama can in any way contribute to solving such dilemmas is very much doubted by the playwright; doubts ironically given voice to by the unrepentant Pokorny, an opera fan:

Das ist das Wunderbare im Theater: man erkennt die eigne Niedertracht, läßt sich erschüttern, beinah bessern, applaudiert wie ein Wilder, und fünf Minuten später pfeift man drauf. - Das nennt man Reinigung. (II, 314)

Perhaps surprisingly, considering the move away from historical settings evident since the mid-1950s, Hochwälder returned to a historical setting in the last of his dramas to deal with Vergangenheitsbewältigung. Indeed, Die Prinzessin von Chimay can in part be viewed as a sequel to his earlier play, Der öffentliche Ankläger, for it reintroduces the heroine of the earlier play, Theresia Tallien, some decades after the fall of Fouquier-Tinville and some name changes later: "TERESA, geborene Cabarrus, geschiedene Marquise Fontenay, geschiedene Bürgerin Tallien, seit fünf Jahren verwitwete Prinzessin von Chimay" (IV, 8).

The plot and its conclusion, particularly in the first published version ${ }^{93}$, not only stretch credibility but can also be seen to be at odds with Hochwälder's earlier attitude to uncovering the past. That Teresa, having been haunted for years by nightmares about Marc-Antoine Jullien, should find that he has assumed a new identity and now is her trusted advisor, and then decide that she cannot live without him and continue to employ him, has led to the interpretation that the play is a call for reconciliation and forgiveness ${ }^{94}$. 92 A delightful touch considering the pre-eminence given to Dwornik's pipe throughout the play!

93 Fritz Hochwälder, Die Prinzessin von Chimay. Komödie in drei Akten (Graz: Styria, 1982). Hereafter referred to as (Die Prinzessin von Chimay, page no.).

94 Cf. Karl Harb, "Im Dienste der Gerechtigkeit", Salzburger Nachrichten, 20. Feb. 1982, 23; 
Certainly, the final scene of the earlier version, in which former persecutor and victim sit down for the customary game of cards, without a word of explanation, and dissolve into laughter, is very reminiscent of the end of the comedy, Der Unschuldige, and does little to belie such an interpretation. Donald G. Daviau has found in the play the strongest argument for his thesis that Hochwälder's later works call for a laying to rest of the past:

Hochwälder insists once more that order and tranquility [sic] are more important to society than justice, particularly when the criminals are people of advanced age whose crimes lie more than a generation in the past. He no longer believes the view of Valprès he once shared, the Dürrenmattian view that injustice must be fought wherever it occurs and that there is no statute of limitation on justice ${ }^{95}$.

Yet the author himself, during a reading of the play in Graz, was at pains to make clear that this was not his intention:

Hochwälder [...] will trotzdem sein Stück nicht als "VersöhnungsKomödie" verstanden wissen, vielmehr zeige es die "Tragik und Ironie des Schicksals", die den konsequenten Humanisten nicht von seinem unerschütterlichen Prinzip abbringt: "Wir müssen der Menschheit zeigen, daß die Forderung nach Gerechtigkeit nie untergeht" $"$.

Indeed, upon closer analysis, the play can be viewed as an ironic commentary of a society, which forty years after the war, cannot fully lay the past to rest, but is morally compromised enough to wish it could. This is most clearly demonstrated by the figure of Teresa, who although haunted by the crimes of Jullien, can scarcely, as anyone familiar with her earlier appearance will know, claim pure innocence: the manner in which she dispatched Fouquier-Tinville to the guillotine required her to use the same tools of the Terror as her mortal enemy, compromising her morally and demonstrating a willingness to use the trappings of power. The detail she provides to Valprès also shows how she continued to thrive on power and prestige, moving from one powerful partner to another (IV, 14-15). Yet despite a life of high social standing and influence, in her old age she finds herself alone and isolated ${ }^{97}$, cut off even from her surviving children, and totally dependent on Maergesse, her "rechte Hand" (IV, 15).

Yet despite the compromises she has made, she still clings, with more than a touch of hypocrisy, to the early ideals of the Revolution:

Lutz Hagestedt, "Der verschwundene Mond", Süddeutsche Zeitung [München], 2. Nov. 1985.

95 Daviau, "Fritz Hochwälder", 261.

96 Elisabeth Willgruber-Spitz, "Gerechtigkeit und klassische Formen", Neue Zeit [Graz], 30. Juni 1984,4 .

97 Once more Hochwälder uses an isolated setting, a Belgian castle, far removed from the glamorous social setting of Paris where Teresa established her reputation, to underscore the fundamental loneliness of his characters. 
Was mir während der Schreckenherrschaft widerfahren ist, empfand ich als besonderes Unrecht, weil ich von 1789 an aus meiner Sympathie für die Revolution keinen Hehl gemacht habe. [...] Mein Herz schlug stets für die Mißhandelten und Unterdrückten. Als ich sechzehn war, verheiratete man mich gegen meinen Willen mit dem Marquis Fontenay, von dem ich mich trennte, weil ich nicht mit einem Aristokraten liiert sein wollte. Dennoch warf man mir unaufhörlich meine Beziehung zur Aristokratie und meine spanische Abstammung vor, obgleich mein Vater bereits in Bayonne geboren war; man stellte mir unablässig nach, als einer erbitterten Feindin der Revolution, mir - die ich vom Bastillensturm begeistert war.

(IV, 23-24)

Certainly, she does help the poor in the area (IV, 16), and during the reign of Robespierre she saved many from execution, earning the admiration of Valprès as "Die Retterin von Bordeaux" (IV, 10), but her ideals did not stop her enjoying the lavish celebrations of the fall of Robespierre, while the masses starved in Paris (IV, 14), or enjoying the luxurious lifestyles of her various men, or even, as an exposed Maergesse suggests, profiting, like her late husband Tallien, from the victims of the Revolution by accepting bribes to save people's lives (IV, 35).

Just as Teresa has completely compromised the beliefs she professes to share, so too does the man she seeks, who, it transpires, is none other than Maergesse. He has more than a little in common with his bureaucratic predecessors, Fouquier-Tinville and Mittermayer. In fact, once exposed, he is prompted to declare he is not like the Public Prosecutor before going on to quote Hochwälder's earlier protagonist almost word for word:

Ah, Madame, Sie sind trotz allem am Falschen - ich bin nicht FouquierTinville, so werden Sie mit mir nicht fertig! - Ja, ich bin Marc-Antoine Jullien gewesen. - Aber vielleicht waren die Fehler, die Mißgriffe, die Verbrechen, die mir anhaften, nichts anderes als der düstere Schatten, den die Revolution warf, jene grandiose Umwälzung, die die Bastille zerstörte, den Königen heillosen Schrecken einjagte und den Fortschritt des Menschengeschlechtes befeuerte wie kein Ereignis zuvor in der dumpfen Geschichte des Erdballs!

$(\mathrm{IV}, 33)^{98}$

As he gets more passionate in his defence, however, he reveals that beneath the surface he is still very much the fanatic Jullien, although he would portray himself as a victim of the Revolution:

98 Compare this to Fouquier's words:

Vielleicht sind die Fehler, die Mißgriffe, die Verbrechen, die Threm Feind anhaften, nichts anderes als der düstere Schatten, den die Revolution wirft - diese grandiose Umwälzung, die die Bastille zerstörte, den Königen heillosen Schrecken einjagte, die Menschenrechte verkündete und den Fortschritt des Menschengeschlechtes befeuerte wie kein Ereignis zuvor in der dumpfen Geschichte des Erdballs. (I, 296) 
Diese schrecklichen Direktiven in die Tat zu setzen war meine verdammte Pflicht und Schuldigkeit. - Deshalb betrachte ich mich als eines der zahllosen Opfer der Revolution. Als das Blut der Freiheit in Strömen floß, sagte ich mir: Es ist das Opfer welches die Gegenwart von Frankreich fordert. Wir beklagten sie, aber wir bringen sie dar, weil wir das Ufer der Zukunft erreichen wollen; wir opfern sie und zugleich uns auf dem Altar des Vaterlandes.

(IV, 34)

He even goes so far as to express regret at failing to deliver Teresa to the guillotine (IV, 35).

Yet for all his professed revolutionary ideals Maergesse has spent the last five years serving the woman whom he felt deserved to die. He, in a way that Dwornik would agree with, is insistent that he was, rather than is Jullien: "Gewesen, Madame" (IV, 33), a distinction he later insists on to Frenelle (IV, 38). Like Mittermayer in the earlier play, he shows himself to be the perfect officious carrier out of duty, for once uncovered he chooses not to leave immediately, but to execute his final duties to Teresa, admittedly in the firm knowledge that he cannot be touched (IV, 38). He even shows himself, like the police inspector, to be unable to comprehend the horrors for which he was earlier responsible, and when he learns that he personally delivered Valprès' father to the guillotine can only respond: "Mein Gott - war das nicht alles schrecklich?" (IV, 40).

Both Teresa and Maergesse, the idealists in the play, are exposed as completely compromised, yet both would like to cling to part of their beliefs. It is left to the third major character, Valprès, to question their ideas, rejecting any idealism as potentially flawed: "Es fragt sich, ob Ideale so erstrebenswert sind. Ideale führen früher oder später zu Exzessen" (IV, 26) ${ }^{99}$.

Valprès is clearly based on the famous investigator of Nazi crimes, Simon Wiesenthal, as the linguistic play in his name indicates: "Val" is French for valley, or the German "Tal", while "près" suggests the French "pré", meaning meadow or, in German "Wiese". Hochwälder even goes so far as to quote Wiesenthal almost literally at one point, when Valprès explains his relentless pursuit of justice:

Noch immer laufen zahlreiche Schwerverbrecher ungeschoren herum. Die Möglichkeiten der Entlarvung schrumpfen von Tag zu Tag. Entweder die Zeugen sterben oder die Verbrecher selbst sterben. Aber solange sowohl die Generation der Verbrecher als auch die Generation der Verfolgten lebt, muß meine Arbeit weitergeführt werden, wenn auch nur als Mahnmal für die Mörder von morgen, die vielleicht schon heute geboren sind.

$$
(\text { IV }, 23)^{100}
$$

\footnotetext{
99 This position, very close to Hochwälder's heart, will be examined more closely in the next chapter.

100 This is very close to Wiesenthal's own words, found in a newspaper article in Hochwälder's Nachlaß:

"Noch immer laufen zahlreiche Verbrecher frei herum, aber unsere Möglichkeiten
} 
He continues his work, even though he is well aware that, through a statute of limitations, the criminals he seeks can no longer be brought to trial:

Es ist richtig, daß die noch lebenden Blutsäufer der Ära Robespierre im Fall einer Entdeckung nichts zu befürchten haben. Aber längst geht es nicht mehr um Vergeltung und Strafe. [...] Heutzutage geht es um etwas grundsätzlich anderes: Alle jene, die seinerzeit die Fabrik von Meudon mit Menschen belieferten, in der man die Häute der Opfer zu Lampenschirmen verarbeitete ${ }^{101}$, müssen ein für allemal nominiert und festgehalten werden, damit in Zukunft nie wieder die Verwertbarkeit von Menschenmaterial erwogen werden kann. Dies das ausschließliche Ziel meiner Tätigkeit [...]

(IV, 10-11)

The futility of seeking revenge for past crimes so monstrous they defy adequate punishment is an issue which is raised several times during the play. Indeed, Teresa, like de Goede before her, does not seek revenge or punishment (IV, 10 ), but merely wants to know what has become of her erstwhile persecutor and would-be murderer, convinced that this knowledge will release her from her nocturnal ordeals (IV, 13). Such is this need that even the shock that her trusted adviser, Maergesse, turns out to be the man she seeks, cannot rob her of the relief of knowing who Jullien really is: "Wie ich mich fühle? - Befreit!" (IV, 36).

The question of revenge is further raised by the minor characters, Frenelle and Joseph. The latter at first desires not only to avenge his mistress but also Frenelle who all those years ago gave herself to Jullien in a vain attempt to save Teresa from further persecution (IV, 17-18). At this stage it is Frenelle that persuades him to forgo vengeance, for she does not wish to be left on her own in her old-age while Joseph is in prison for murder, and he concedes: "Was nützt uns Rache nach einem Menschenalter?" (IV, 19). Yet, when Maergesse is exposed it is Frenelle who insists on vengeance, only for Valprès to intercede, in true Wiesenthal fashion ${ }^{102}$ : "Mach deine Hand nicht schmutzig an dem entlarvten Schuft!" (IV, 33).

Nevertheless, despite the rejection of revenge, a theme which echoes the earlier drama, Donadieu, the play should not be seen as a call for forgetting and forgiving the past. Admittedly, the ending of the 1982 version can easily lead to the conclusion, but the changes Hochwälder made to the final version of the play, which appeared in Dramen IV as the "endgültige Fassung", are highly significant. Daviau, in his effort to support his "order and tranquility [sic]"

schrumpfen. Entweder sterben Zeugen, oder die Nazis selber sterben. Doch solange sowohl die Generation der Verbrecher als auch die Generation der Verfolgten lebt, muss die Arbeit weitergehen, wenn auch nur als Momento für die Mörder von morgen, die heute bereits geboren sind".

- Anonym, "Nazijäger Simon Wiesenthal: 'Ein letztes Büro schliesst man nicht", CoopZeitung, Nr. 5, 29. Jan. 1981.

101 Such barbaric practices are also referred to in the earlier play, Der öffentliche Ankläger (I, 302), and clearly evoke the horrors of the Third Reich [see Chapter 3].

102 Cf. Wiesenthal, Justice not Vengeance. 
thesis, is rather selective in noting these changes, only observing the omission of Maergesse's and Teresa's giggling at the end (Die Prinzessin von Chimay, $44)^{103}$. This fails to take into account the important addition to the closing conversation:

TERESA: [...] Wir halten es wie alltäglich: Bei Einbruch der Abenddämmerung widmen wir uns dem Kartenspiel. Und wenn wir die Vergangenheit jetzt begraben, dann ist damit - wohlgemerkt: nichts aus der Welt geschafft und nichts entschuldigt oder gar verziehen! 104 - Ich weiß nun, wie mein Mörder aussieht - Ihr Anblick schreckt mich künftig nicht. - Was sollt ich Ihnen denn tun? - Für das, was Sie und Ihresgleichen verübten, gibt es keine entsprechende Strafe, die schwerste wäre viel zu mild! [...] Wer bin ich denn, was bin ich noch? - Die einst blutjunge schöne Bürgerin Tallien, die mit ihren schwachen Händen geholfen hatte, die Guillotine umzustoßen. - Und heute, jetzt und hier? - Eine steinreiche, alleinstehende, hoffnunglos vereinsamte alte Frau, die ohne Stab und Stütze ihres weiland Mörders verloren ist. - Verstehen Sie mich?

MAERGESSE: Ich bemühe mich jedenfalls. - Wahr ist: auch ich stehe als alter Mann allein.

TERESA: Zuletzt möchte ich bloß noch eines wissen: Wie konnten Sie sich vor fünf Jahren um die Stelle bei mir bewerben, wo Sie doch wußten, wer Sie sind!

MAERGESSE: Hand aufs Herz - ich weiß es nicht mehr.

TERESA: Erstaunlich immerhin, daß wir uns nach alldem jetzt als Komplizen beim Kartenspiel gegenübersitzen - wie?

MAERGESSE: Nein, Madame - nichts ist erstaunlich in unserer Zeit, denn alles, restlos alles ist möglich. - Das Unwahrscheinliche ereignet sich vor unsern Augen Tag für Tag.

Incredible though this final scene may be, its significance should not be overlooked. Teresa categorically states that the past cannot be forgotten or forgiven, indeed it is the uncovering of the past that has finally given her peace of mind. Yet equally no punishment or retribution can possibly undo the damage that has been done by previous crimes. Furthermore, while it seems implausible that the two might sit down and play cards as if nothing had happened, it is suggested that this is no more incredible than the crimes perfectly normal individuals can commit in certain circumstances. As Kurt Wimmer astutely observed, the present circumstances both characters find themselves in requires a compromise that can be seen as a metaphor for modern Austria: "Die ironische Pointe des Stückes besteht nun darin, daß sich Teresa mit ihrer 103 Daviau, "Fritz Hochwälder", 261.

104 This is very similar to the words used by Dwornik at the end of Befehl: "Damit ist nichts aus der Welt geschafft, und nichts - aber auch nichts - entschuldigt" (II, 336). 
Vergangenheit arrangiert: Maergesse und sie bleiben beisammen" 105.

Whether justice can possibly be achieved after the terrible events of the Third Reich, or whether such inhumanity can be avoided in the future are questions that cannot be definitively answered. However, each of the four plays, Holokaust, Der Himbeerpflücker, Der Befehl and Die Prinzessin von Chimay, demonstrate that a sound, healthy basis for present-day society cannot be built without acknowledging the lessons of the past, for without facing them, the mentality that allowed such inhumanity to be carried out, be it in the name of ideology, following orders, or self-advancement, can easily come to the fore again. Yet, there is undoubtedly an element of pessimism running through these plays which suggests that even though the past cannot and should not be buried, confronting it achieves little. Throughout Hochwälder's dramas there is a deep suspicion of ideologies of any persuasion, of any attempt to create a better world, for all such ideals are open to human corruption. But in the scepticism lies a still deeper concern: is human nature so flawed that humanity can never learn and is ultimately doomed to destroy itself by its own flawed make-up?

105 Kurt Wimmer, "Dem Schrecknis mit der Komödie begegnen", Kleine Zeitung [Graz], 30. Juni 1984, 12. 